\title{
A multiobjective DEA model to assess the eco- efficiency of major cereal crops production within the carbon and nitrogen footprint in China
}

\section{Zhongdu Chen}

China national rice research institute

\section{Chunchun Xu}

China national rice research institute

Long Ji

China national rice research institute

fuping fang ( $\nabla$ czdgo@163.com )

China national rice research institute https://orcid.org/0000-0003-0739-2900

\section{Research}

Keywords: Carbon footprint, Nitrogen footprint, Eco-efficiency, Life cycle assessment, Data envelopment analysis, Grain crops

Posted Date: March 18th, 2020

DOI: https://doi.org/10.21203/rs.3.rs-17654/v1

License: (c) (i) This work is licensed under a Creative Commons Attribution 4.0 International License. Read Full License 
1 A multiobjective DEA model to assess the eco-efficiency of major cereal crops

2 production within the carbon and nitrogen footprint in China

3

4 Zhongdu Chen ${ }^{\mathrm{a}}$; Chunchun $\mathrm{Xu}^{\mathrm{a}}$; Long Ji ${ }^{\mathrm{a}}$; Fuping Fanga, *

$5 \quad$ *Corresponding author, czdgo@163.com (Fuping Fang). Tel: +86 0577- 63100133. Full postal address:

6 China National Rice Research Institute, No.359 Tiyuchang Rd, Hangzhou, Zhejiang 310006, China;

$7 \quad{ }^{a}$ China National Rice Research Institute, Hangzhou 310006, P.R.China 


\section{8}

\section{Abstract:}

[Background]Agricultural production systems are facing the challenges of increasing food production while reducing environmental cost, particularly in China. Understanding the eco-efficiency of the staple food crop production contributes to sustainable agriculture. In this study, the eco-efficiency of rice, wheat and maize production within the carbon $(\mathrm{C})$ footprints $(\mathrm{CF})$ and nitrogen $(\mathrm{N})$ footprint $(\mathrm{NF})$ at a province scale based on 555 farm survey data from China was measured in which a combination of life cycle assessment (LCA) and data envelopment analysis (DEA) was used. [Results] The results showed that the synthetic $\mathrm{N}$ fertilizer applications and $\mathrm{CH}_{4}$ emissions dominated the $\mathrm{CF}$ of crop production, while $\mathrm{NH}_{3}$ volatilization was the main contributors to the $\mathrm{NF}$ in the grain crop production process. Based on DEA-based sustainability performance assessment results, the eco-efficiency of major cereal crops production were all found to be inefficient (eco-efficiency $<1)$. An increase in yields had only limited effects on improvement in eco-efficiency of rice, wheat and corn production because the yield increase potential rates were very small $(0.1 \sim 3.4 \%)$, and there were no significant differences in increase potentials of yields between provinces. From a perspective of environmental impact reduction potential rates, GWP $(22.7 \sim 25.1 \%)$ was more important for the environmental mitigation target than $\mathrm{Nr}(10.9 \sim 17.9 \%)$ in rice production, but the opposite scenario appears in wheat and corn production. [Conclusions] Improving crop management practices by reducing $\mathrm{N}$ fertilizer use and adopting water-saving irrigation technology could be strategic options to mitigate climate change and eutrophication and improve the eco-efficiency of the staple food crop production in Chinese agriculture.

\section{Keywords:}

Carbon footprint;

Nitrogen footprint;

Eco-efficiency;

Life cycle assessment;

Data envelopment analysis;

Grain crops 


\section{Background}

Climate change and eutrophication pollution are one of the most important environmental problems [1], threatening significantly the well-being of humankind and other creatures on earth. Agriculture is one of the principal contributors to anthropogenic greenhouse gas (GHG) emissions, especially non- $\mathrm{CO}_{2}$ emissions [i.e., methane $\left(\mathrm{CH}_{4}\right)$ and nitrous oxide $\left(\mathrm{N}_{2} \mathrm{O}\right)$ emission].On the contrary, with economic development and population growth, people began to increase energy, fertilizers, pesticides and agricultural film to maintain food production, through which more greenhouse gas emission was produced. Moreover, a significant proportion of the nitrogen $(\mathrm{N})$ annual application of fertilizer as reactive $\mathrm{N}\left(\mathrm{Nr}\right.$; all $\mathrm{N}$ species except $\left.\mathrm{N}_{2}\right)$ is released into the environment, causing a series of environmental problems such as air pollution, stratospheric ozone depletion and eutrophication [2]. Therefore, modern intensive agricultural and food markets have been demanding better products with less impact on the environment. Eco-efficiency is a concept used to analyze farm sustainability, which relates the economic value of an activity to how the environment is influenced. It is playing a more and more important role in evaluating the efficiency of economic activities related to natural resources and ecological deterioration and has begun to attract academic attention [3].

In agricultural production as well as in other areas, the environmental impacts can be quantified by different indicators, which can be measured by the Life Cycle Assessment (LCA) [4], which has been proven to be a valuable tool for addressing the environmental impact of various agriculture production systems, in which the identification of the subsystems that contribute most to the environmental impact overall and the comparison of products and processes with the same function was involved. Among the different environmental burdens, global climate change and local eutrophication pose a serious threat to the well-being of humankind and other organisms on earth. The LCA indicator that evaluates these burdens was the carbon $(\mathrm{C})$ footprint $(\mathrm{CF})$ and $\mathrm{N}$ footprint $(\mathrm{NF})$. The $\mathrm{CF}$ is widely used in comparing the impacts of different products on climate change, and is used to explore mitigation measures for greenhouse gas emissions [5]. While the NF indicates the total amount of $\mathrm{Nr}$ lost to the environment due to human activities [6]. To understand tradeoffs or synergies and possible simultaneous mitigation practices, integrated assessments are preferred. Several of these attempted to establish a single score for the environmental impact of wheat production using weighting, which aggregates the results of standardized indicators for each environmental impact category and assigns weighting factors based on their relative importance [7]. However, weight factors based on value selection are subject to subjective 
and political influences, as well as lack of knowledge on resource consumption and pollutant emission, which complicates the derivation of weight factors [7].

Eco-efficiency gathers the economic and environmental dimensions to relate a product to environmental impacts. A primary challenge of eco-efficiency measurement is the integration of several different environmental impact categories with different measurement units into a single environmental damage index. The eco-efficiency set is a collection of economic and environmental dimensions, linking products to environmental impacts. One of the main challenges of eco-efficiency measurement is the integration of several different environmental impact categories and different units of measurement into a single environmental damage index. As a linear programming based frontier estimation tool, data envelopment analysis (DEA) is used to quantify and measure relative efficiency of a set of similar entities of Decision Making Units (DMUs) having multiple inputs and/or outputs. Furthermore, this union provides quantitative benchmarks to guide the performance of any system in terms of environmental sustainability. At present, different methodologies were proposed to implement the LCA + DEA approach, aiming at assessing performance of multiple input/output for a large number of entities on the operational and environmental levels. The most commonly used methods are the three-step method [8] and the five-step method [9]. Recently, Rebolledo-leiva et al. [10] proposed a four-step method which focuses on increasing output and decreasing CF through DEA model, and then determines the target of resources contributing to CF. However, in all these methods, the DEA model used only identifies an inefficient DMUs, which may not be feasible from an operational or management perspective. Through a multiobjective DEA model, more flexibility is allowed in searching for feasible efficient targets in the decision-making process which is more applicable to agricultural systems, and has been widely applied in various fields. There is a large amount of literature that evaluates eco-efficiency based on DEA models, which is available at a range of scales, spanning the micro level to the macro level. At a regional scale, Otsuka [11] evaluated eco-efficiency with a DEA model to confirm the Porter hypothesis in Japan's manufacturing sector and concluded that GHG emissions, which can be reduced by increasing funding for technological innovation, are the major factor accounting for inefficiency. In order to determine the level of operational input efficiency of each farm, Iribarren et al. [8] conducted a study using the LCA+DEA method on 72 dairy farms. They benchmarked potential reductions in inputs while calculating the environmental benefits associated with these reduction targets, and concluded that a total of 31 farms were considered effective. The 
focus of existing literature in China is mainly directed to ecological efficiency on the national and provincial levels. The spatial distribution of 273 cities in China from 2003 to 2015 was explored by Huang et al. [12] with urban agglomeration as the index, and the urban ecological efficiency was evaluated by DEA method. The ecological efficiency of 281 prefecture-level cities in China from 2006 to 2013 was measured by Bai et al. [13] through the envelopment analysis model of super-efficiency data, and a new comprehensive evaluation index system of urbanization was proposed. However, it is still unclear the eco-efficiency of major cereal crops production in China.

In China, agriculture is one of the most predominant GHG emission sources globally, including $50 \%$ of the total $\mathrm{CH}_{4}$ and $92 \%$ of the total $\mathrm{CO}_{2}$ emissions in 2010 [14]. In addition, China is the greatest consumer of $\mathrm{N}$ fertilizer alt $45 \mathrm{Mt}$, accounting for $37.6 \%$ of world consumption in 2014, about $27 \mathrm{Tg}$ $\mathrm{yr}^{-1}$ of $\mathrm{N}$ fertilizer was applied for crop production during 2001 2010 in China [5], mainly to produce rice, wheat and maize. At present, the large input and low efficiency of resources and energy in food production aggravate the degradation of climate and environment [15]. To make matters worse, grain yields in China has stagnated since 2010 , with $79 \%$ of its rice crop, $56 \%$ of its wheat and $52 \%$ of its maize. Meanwhile, the use of various related resources, such as pesticides and fertilizers, is likely to continue to increase in any case [16]. In other words, many Chinese farmers may buy (and use) more and more agricultural materials, but their net economic benefits have not been significantly improved [17]. Producers are more concerned with eco-efficiency, which, according to the world business council for sustainable development (WBCSD), means producing more products with less environmental impact and fewer resources. Therefore, the objectives of the present investigation were: (1) to estimate the CFs and NFs of rice, wheat and maize from farm survey data using LCA assessment; (2) to analyze the prime driving forces of CFs and NFs of three grain crops on province levels for the first time; (3) to assess the eco-efficiency of rice, wheat and maize on province levels using a multiobjective LCA+DEA model.

\section{Material and methods}

\section{Study region}

Study sites that represent the major crop production areas of China were selected (Fig. 1). Generally, the typical provinces of rice growing were selected in Jiangxi and Hunan with a warm and humid climate in southern China. The water management in local rice in this area was irrigated normally 
under intermittent flooding conditions during the rainy season. Meanwhile, we chose Jiangsu and Anhui provinces to conduct research on winter wheat. Corn was a typical grain crop production system in Jilin and Hebei, where there was a humid climate, while maize rotation in summer and winter was a typical sub-humid climate in Hebei. Sites of the farm survey across these representative crop production areas are shown in

\section{System boundary}

The focus of this study is directed to the environmental impact and GHG emissions of the three grain crop production in the surveyed region. For this purpose the input/output items of the model DMU shall be established within an LCA+DEA framework. Fig. 2 shows the elements involved in the LCA +DEA study of the farms was assessed for the entire production chain of crop. For LCA analysis, the GHGs and $\mathrm{Nr}$ emissions included the following: 1) electricity generation, gasoline and diesel production from mechanical jobs (tilling, seeding, irrigating, harvesting, and packing); 2) manufacturing, storage, and transportation of agricultural materials (including $\mathrm{N}$ fertilizers, phosphate fertilizers, potassium fertilizers, pesticides, seeds and film); (3) total $\mathrm{CH}_{4}$ and $\mathrm{N}_{2} \mathrm{O}$ seasonal emissions from fields, as well as $\mathrm{NH}_{3}$ volatilization, and $\mathrm{NO}_{3}{ }^{-}$and $\mathrm{NH}_{4}{ }^{+}$leaching during crop growing periods. For DEA, labor, machinery, diesel fuel, water for irrigation, electricity, chemical fertilizer, pesticides, seeds and film were considered as the inputs. Direct GHG emissions, crop yields and $\mathrm{Nr}$ emissions to air are the main outputs at the system boundary assuming that all selected analysis items are independent of each other

\section{Data sources}

The farmer survey is a multiphase survey of major cereal crops farms in six provinces of China. In this study, stratified random sampling was adopted. The questionnaire consisted of four parts: (1) amounts of $\mathrm{N}$, phosphate, potassium fertilizers, and pesticides used for each crop production; (2) farm mechanical operations (e.g. methods of soil tillage, harvesting); (3) water management practices such as tube or well irrigation; and (4) farm area and grain yield of each crop. There were 40 representatives were conducted as pre-tested at Swan village, Ningxiang county of Hunan in order to test the reasonability of the questionnaire. Finally, effective improvements were made to the questionnaire based on the evaluation and recommendations. During the predictive test, farmers reported that they 
had encountered considerable problems in answering questions about their financial status. Therefore, to avoid motivational questions, questions related to the financial status of the farm were removed from the list. Two towns and villages in each county and 2 village in each town were selected for field investigation. 20 households were randomly selected from each village and head of households (farmers) was interviewed face to face. Household farms were divided into two categories of small sized ( $<0.7$ ha), middle sized $(2 \sim 7$ ha) and large sized household farms ( $>20$ ha) according to the farm size data obtained in the survey based on the land planning standards of the ministry of agriculture and village of the People's Republic of China. Overall, A 600 investigate dataset was collected with farmers from all six province. Of this sample, about 555 surveys were fully completed and could be used.

\section{Carbon footprint calculation}

With the application of farm-gate principles of agricultural life cycle assessment that are generally accepted, researchers established the system boundary concerning cereal crops from sowing to harvesting. Using the global warming potential (GWP) for a timespan of a century, the GHG emissions were estimated [18]. According to the life cycle inventory, the $\mathrm{CF}\left(\mathrm{kgCO}_{2} \mathrm{eq} \mathrm{kg}^{-1}\right)$ for each crop in each of the provinces concerned was calculated using the following equation:

$\mathrm{CF}_{\mathrm{y}}=\mathrm{CE}_{\mathrm{t}} / \mathrm{Y}$

$\mathrm{CE}=\mathrm{CE}_{\text {input }}+25 \times \mathrm{CH}_{4}+298 \times \mathrm{N}_{2} \mathrm{O}$

$\mathrm{CE}_{\text {input }}=\sum \mathrm{I}_{\mathrm{n}} \times \mathrm{C}_{\mathrm{n}}$

Where $\mathrm{CF}_{\mathrm{y}}$ is the total $\mathrm{CF}$ for each $\mathrm{kg}$ of the rice, wheat, and maize produced $\left(\mathrm{kgCO}_{2}-\mathrm{eq} \mathrm{kg}^{-1}\right)$; yield is the grain yield of grain produced $\left(\mathrm{t} \mathrm{ha}^{-1}\right) . \mathrm{CE}_{\mathrm{t}}$ is the $\mathrm{GHG}$ emissions for 100 years of all the trace gases with an impact on radiative forcing [19] associated with the entire life cycle concerning the production of rice, wheat, and maize $\left(\mathrm{kgCO}_{2}\right.$-eq ha $\left.{ }^{-1}\right)$. $\mathrm{CE}_{\text {input }}$ is the amount of indirect emissions of agriculture inputs; $I_{n}$ and $C_{n}$ are the each item of agricultural input and its GHG emissions coefficient (Table 1), respectively. For most of inputs, the conversion coefficients of $\mathrm{CO}_{2}$ equivalent were retrieved from the Chinese Life Cycle Database (CLCD v0.7, IKE Environmental Technology CO., Ltd, China). In the meantime, those of pesticides and seeds were retrieved from Ecoinvent v2.2 (Swiss Centre for Life Cycle Inventories, Switzerland). $\mathrm{CH}_{4}$ and $\mathrm{N}_{2} \mathrm{O}$ are the amount of average non- $\mathrm{CO}_{2}$ emissions on an annual basis. The constants 25 and 298 represent the GWP coefficients for $\mathrm{CH}_{4}$ and $\mathrm{N}_{2} \mathrm{O}$ (based on a 100-year time frame). 
189 Guided by the 2006 IPCC Guidelines for National Greenhouse Gas Inventories, the $\mathrm{CH}_{4}$ and $\mathrm{N}_{2} \mathrm{O}$ 190 emissions from paddy fields were estimated [19]. Using the following equation, the $\mathrm{CH}_{4}$ emissions 191 released directly from submerged paddy field were estimated:

$192 \mathrm{CF}_{\mathrm{CH}_{4}}=\mathrm{EF}_{\mathrm{i}, \mathrm{j}, \mathrm{k}} \times \mathrm{t}_{\mathrm{i}, \mathrm{j}, \mathrm{k}} \times 25$

$\mathrm{EF}_{\mathrm{i}, \mathrm{j}, \mathrm{k}}=\mathrm{EF}_{\mathrm{C}} \times \mathrm{SF}_{\mathrm{W}} \times \mathrm{SF}_{\mathrm{P}} \times \mathrm{SF}_{\mathrm{O}}$

$\mathrm{SF}_{\mathrm{O}}=\left(1+\sum_{\mathrm{i}} \mathrm{ROA}_{\mathrm{i}} \times \mathrm{CFOA}_{\mathrm{i}}\right)^{0.59}$

$\mathrm{ROA}_{\mathrm{i}}=\mathrm{Y} \times 0.623 \times 0.5 \times 0.85$

196 In the above equations, $\mathrm{CF}_{\mathrm{CH} 4}$ represents the annual per unit methane emission from rice cultivation $197\left(\mathrm{kgCO}_{2}-\mathrm{eq} \mathrm{ha}{ }^{-1}\right) ; \mathrm{EF}_{\mathrm{ijk}}$ is a emission factor on a daily basis $\left(\mathrm{kgCH}_{4} \mathrm{ha}^{-1} \mathrm{day}^{-1}\right) ; \mathrm{t}_{\mathrm{j} \mathrm{k}}$ is the growing timespan of rice (day); i, j, and k stands for different ecosystems, water regimes, organic amendments' type and amount, and other conditions influencing $\mathrm{CH}_{4}$ emissions from rice production; and 25 is $\mathrm{CH}_{4}$ 's relative molecular warming forcing of in a 100-year time horizon [19]. While $\mathrm{EF}_{\mathrm{c}}$ is the baseline emission factor for fields without organic amendments that are continuously flooded, $1.30 \mathrm{~kg} \mathrm{CH}_{4} \mathrm{ha}^{-1}$ day $^{-1} \cdot \mathrm{SF}_{\mathrm{w}}$ and $\mathrm{SF}_{\mathrm{p}}$, serves as a scaling factor that is used in accounting for the differences in water regime both during the rice growing period and before rice transplantation. $\mathrm{SF}_{\mathrm{o}}$ serves as the scaling factor which varies with regard to both type and amount of organic amendment that is used. $\mathrm{ROA}_{\mathrm{i}}$ represents organic amendment' application rate. $\mathrm{CFOA}_{i}$ in (6) is the conversion factor, which is concerned with organic amendment i; 0.623 is rice's residue/grain ratio, 0.5 is the coefficient of rice straw retention, this figure indicates the percentage of the amount of straw retention compared with total straw under the framework of present technological level [20], 0.85 is the conversion coefficient, which indicates the ratio of fresh weight to dry weight for rice straw [21].

As is shown in the following equation, the estimated $\mathrm{N}_{2} \mathrm{O}$ emissions released directly from $\mathrm{N}$ fertilizer application is depicted

214 In the above equation, $\mathrm{N}$ is the amount of $\mathrm{N}$ fertilizer that applied during a single crop season; $\mathcal{E}$ is the default emission factor of $\mathrm{N}_{2} \mathrm{O}$ emission of applied $\mathrm{N}$ fertilizer. Emission factors of synthetic $\mathrm{N}$ fertilizer use in dry crops and submerged rice paddies were adopted respectively from IPCC (2006) [19] and Zou et al. [22] (Dry cropland, $0.01 \mathrm{~kg} \mathrm{~N}_{2} \mathrm{O}-\mathrm{N} \mathrm{kg}^{-1}$, Rice paddy, $0.0073 \mathrm{~kg} \mathrm{~N}_{2} \mathrm{O}-\mathrm{N} \mathrm{kg}^{-1}$ ); $44 / 28$ is the 
molecular conversion factor of $\mathrm{N}_{2}$ to $\mathrm{N}_{2} \mathrm{O} ; 298$ reveals the global warming potential (GWP) of $\mathrm{N}_{2} \mathrm{O}$ relative to $\mathrm{CO}_{2}$ over a 100-year time horizon.

\section{Nitrogen footprint calculation}

In this study, the NF served as an indicator of the total direct N-losses to the environment that occur for the production of one unit of (food) product, measured in $\mathrm{g} \mathrm{N} / \mathrm{kg}$ food product. The eutrophication potential was chosen to assess the impact which is associated with $\mathrm{Nr}$ emissions and losses during the period of grain crop production. Based on ISO 14044 [23], the NF of grain crop produced was calculated.

$\mathrm{NF}_{\mathrm{y}}=\mathrm{NE}_{\mathrm{t}} / \mathrm{Y}$

$\mathrm{NE}_{\mathrm{t}}=\mathrm{NE}_{\text {input }}+\mathrm{NV}_{\mathrm{NH}_{3}}+\mathrm{NE}_{\mathrm{N}_{2} \mathrm{O}}+\mathrm{NL}_{\mathrm{NO}_{3}^{-}}+\mathrm{NL}_{\mathrm{NH}_{4}^{+}}$

$\mathrm{NE}_{\text {input }}=\sum \mathrm{I}_{\mathrm{n}} \times \mathrm{N}_{\mathrm{n}}$

As is shown above, $\mathrm{NE}_{\mathrm{t}}$ is the total $\mathrm{Nr}$ emission which is linked with the entire life cycle of the production of grain crop $\left(\mathrm{gN}_{\mathrm{e}} \mathrm{eq} \mathrm{ha} \mathrm{h}^{-1}\right)$. The $\mathrm{Nr}$ emission during the process of production of kinds of agricultural inputs and the field during the process of grain crop production was included; $\mathrm{NE}_{\text {inputs }}$ is the indirect total amount of $\mathrm{Nr}$ emissions. It is associated with agricultural input applications and is calculated through multiplying the factual use amount of kinds of agricultural inputs $\left(\mathrm{I}_{\mathrm{n}}\right)$ by those emission factors $\left(\mathrm{N}_{\mathrm{n}}\right)$ from IKE eBalance v3.0 (IKE Environment Technology CO., Ltd, China) (Table 1); The $\mathrm{Nr}$ emission from field consists of $\mathrm{NH}_{3}$ volatilization, $\mathrm{N}_{2} \mathrm{O}$ emission, $\mathrm{NO}_{3}{ }^{-}$and $\mathrm{NH}_{4}{ }^{+}$leaching. The amount of emission was calculated through multiplying pure $\mathrm{N}$ use amount by relative loss coefficient. Guided by the manual published internationally, the eutrophication potential value is converted into by multiplying the eutrophication potential value by the eutrophication potential factor.

$\mathrm{NE}_{\mathrm{N}_{2} \mathrm{O}}=\mathrm{N} \times \varepsilon \times 44 / 28 \times 0.476 \times 1000$

$\mathrm{EV}_{\mathrm{NH}_{3}}=\mathrm{N} \times \emptyset \times 17 / 14 \times 0.833 \times 1000$

$\mathrm{NL}_{\mathrm{NO}_{3}^{-}}=\mathrm{N} \times \sigma \times 62 / 14 \times 0.238 \times 1000$

$\mathrm{NL}_{\mathrm{NH}_{4}^{+}}=\mathrm{N} \times \gamma \times 18 / 14 \times 0.786 \times 1000$

In the four equations above, $\phi$ is the $\mathrm{NH}_{3}$ volatilization loss coefficient. For rice, wheat and maize, it's $0.338,0.275$ and 0.226 respectively [24]; $\sigma$ is the $\mathrm{NO}_{3}{ }^{-}$leaching coefficients. For rice, wheat and maize, it's $0.305,0.606$ and 0.175 respectively; $\gamma$ is the $\mathrm{NH}_{4}{ }^{+}$leaching coefficients. For rice, it's 0.339 . For wheat, it's 0.190 . For maize, it's $0.043 .17 / 14,62 / 14$ and $18 / 14$ are the molecular weight ratios of $\mathrm{NH}_{3}$ 
to $\mathrm{NH}_{3}-\mathrm{N}, \mathrm{NO}_{3}{ }^{-}$to $\mathrm{NO}_{3}-\mathrm{N}$, and $\mathrm{NH}_{4}^{+}$to $\mathrm{NH}_{4}^{+}-\mathrm{N}$, respectively; For $\mathrm{NH}_{3}\left(\mathrm{kgN}^{-e q ~ k g}{ }^{-1}\right.$ of $\left.\mathrm{NH}_{3}\right), \mathrm{N}_{2} \mathrm{O}$

$\left(\mathrm{kgN}^{-e q ~ \mathrm{~kg}^{-1}}\right.$ of $\left.\mathrm{N}_{2} \mathrm{O}\right), \mathrm{NO}_{3}^{-}\left(\mathrm{kgN}^{-e q ~ \mathrm{~kg}^{-1}}\right.$ of $\left.\mathrm{NO}_{3}^{-}\right)$and $\mathrm{NH}_{4}^{+}\left(\mathrm{kgN}-\mathrm{eq} \mathrm{kg}^{-1}\right.$ of $\left.\mathrm{NH}_{4}^{+}\right), 0.833,0.476$,

0.238 and 0.786 are eutrophication potential factors, respectively, those related applied eutrophication

251 potential factors were sourced from the CML2002 methodology [25]; 1000 is a unit conversion factor $\left(\mathrm{g} \mathrm{kg}^{-1}\right)$.

\section{SBM-Undesirable Super efficiency model}

On the basis of previous work, this study adopts the slack efficiency measure DEA (SBM-DEA) model, which can take into account the influence of poor output (such as pollution) on efficiency [26]. Compared with the traditional CCR and BCC models, in the SBM model, relaxation variables are directly added to the objective function of the undirected SBM-DEA model with bad output [26] is used to measure efficiency, which is indicated by $\rho$ of decision-making units $\left(D_{M} U_{s}\right)$ under evaluation $\left(\mathrm{xik}, \mathrm{y}_{\mathrm{rk}}^{\mathrm{g}}, \mathrm{y}_{\mathrm{tk}}^{\mathrm{b}}\right)($ where $\mathrm{o}=1, \ldots, \mathrm{k})$. This model provides for minimization of the following fractional objective function, which therefore implies the maximization of slack variables The model provides minimization of the following fractional objective function, which means maximization of the relaxation variable $s_{i}^{-}, s_{r}^{g}, s_{t}^{b}$. Assuming that the $\mathrm{DMU}_{\mathrm{s}}$ set is $\mathrm{j}=\{1,2, \ldots, \mathrm{n}\}$, where each DMU has $\mathrm{m}$ inputs, $\mathrm{S}_{1}$ desirable outputs, and $\mathrm{S}_{2}$ undesirable outputs.

$$
\begin{cases}\rho^{*}= & \min \frac{1-\frac{1}{m} \sum_{i=1}^{m} \frac{s_{i}^{-}}{x_{i k}}}{1-\frac{1}{s_{1}+s_{2}}\left(\sum_{r=1}^{s_{1}} \frac{s_{r}^{g}}{y_{r k}^{g}}+\sum_{t=1}^{s_{2}} \frac{s_{t}^{b}}{y_{t k}^{b}}\right)} \\ \text { s.t. } \quad & \sum_{j=1, j \neq k}^{n} x_{i j} \lambda_{j}-s_{i}^{-} \leq x_{i k} \\ & \sum_{j=1, j \neq k}^{n} y_{r j}^{g} \lambda_{j}+s_{r}^{g} \geq y_{r k}^{g} \\ & \sum_{j=1, j \neq k}^{n} y_{t j}^{b} \lambda_{j}-s_{t}^{b} \leq y_{t k}^{b} \\ & 1-\frac{1}{s_{1}+s_{2}}\left(\sum_{r=1}^{s_{1}} \frac{s_{r}^{g}}{y_{r k}^{g}}+\sum_{t=1}^{s_{2}} \frac{s_{t}^{b}}{y_{t k}^{b}}\right)>0 \\ & s^{-} \geq 0, s^{g} \geq 0, s^{b} \geq 0, \lambda \geq 0 \\ & i=1,2, \ldots, m ; r=1,2, \ldots, s_{1} \\ & t=1,2, \ldots, s_{2} ; j=1,2, \ldots, n(j \neq k)\end{cases}
$$

where: $\rho, s_{i}^{-}, s_{r}^{g}, s_{t}^{b}$ are the efficiency score, excess input, good output deficit, and excess of undesirable output, and the $\mathrm{DMU}_{\mathrm{o}}$ is defined as efficient in the presence of the eco-environment when $\rho=1$ and consequently $s_{i}^{-}=s_{r}^{g}=s_{t}^{b}=0$. When there is an efficiency loss in the DMU $\left(\rho^{*}<1\right)$, based on the relaxation variables $s^{-} 、 s^{g} 、 s^{b}$, the sources of ecological efficiency loss can be decomposed into:

(1) Input redundancy $\left(I E_{x}=\frac{1}{m} \sum_{i=1}^{m} \frac{s_{i}^{-}}{x_{i k}}\right)$, represents the reducible proportion of input factors.

Insufficient expected output $\left(I E_{y^{g}}=\frac{1}{s_{1}+s_{2}} \sum_{r=1}^{s_{1}} \frac{s_{r}^{g}}{y_{r k}^{g}}\right)$, indicates the expansion ratio of expected output, 
(3) Unexpected output redundancies $\left(I E_{y^{b}}=\frac{1}{M+I} \sum_{i=1}^{I} s_{i}^{u} / u_{i 0}\right)$, indicate a reduction in the proportion of undesired output. The objective function is normalized, allowing for comparison of the efficiency scores between the observations. In addition, the bad output, even though it is not transferred, is treated as input in the constraint, but as output in the target function, which is in the denominator.

\section{Statistical analysis}

Data processing was performed using Microsoft Office Excel 2010 and all statistical analyses were conducted using IBM SPSS Statistics, windows Version 22 (IBM Corp., Armonk, NY, USA, 2013). One-way ANOVA and the least significant difference test (LSD) were used to check the differences between farm size classes and regions. The standard $P<0.05$ was used as the confidence level for statistical significance.

\section{Results}

\section{Farm size, grain yield and agricultural input}

There were significant differences in crop yield, farm size and input of agricultural capital among the different crop production. The main farm size from the surveyed farms was $0.1 \sim 0.5$ ha in size for rice, wheat and maize, accounted for $\sim 80 \%$ of total farmers, which showing the great fragmentation of China's croplands. The farm size of the rice and wheat were larger than those of the maize in the surveyed farms. Among the rice, wheat, and maize production, the CF and NF of three crops all showed an increasing trend with the increase of crop farm size classes (Table 4). The average yields from surveyed farms ranged from 4.9 to $6.5 \mathrm{t} \mathrm{ha}^{-1}$ for the rice, 4.9 to 6.7 for wheat and 6.1 to $8.4 \mathrm{t} \mathrm{ha}^{-1}$ for maize, respectively. The highest of yields of grain crop production was found in the maize production. Grain yield of rice was higher in Hunan than in Jiangxi, and those of wheat and maize were no significant difference between Jiangsu and Anhui, Hebei and Jilin. The life cycle inventory dataset, consisting of agricultural inputs and fields, was presented, in detail, based on the above defined system boundaries (Table 2). The input from diverse forms of synthetic fertilizers followed the order: $\mathrm{N}$ fertilizers $>\mathrm{P}_{2} \mathrm{O}_{5}$ fertilizers $>\mathrm{K}_{2} \mathrm{O}$ fertilizers for rice and wheat. $\mathrm{N}$ fertilizer use ranged from $141.7 \mathrm{~kg} \mathrm{~N}$ $\mathrm{ha}^{-1}$ to $460.6 \mathrm{~kg} \mathrm{~N} \mathrm{ha}^{-1}$ across the farms surveyed. The mean $\mathrm{N}$ application rate was the highest for rice (363.2 $\mathrm{kg} \mathrm{N} \mathrm{ha}^{-1}$ ) and the lowest for maize $\left(172.8 \mathrm{~kg} \mathrm{~N} \mathrm{ha}^{-1}\right)$. For wheat production, $\mathrm{N}$ was applied in a higher rate in Jiangsu than that in Anhui. While for maize, the $\mathrm{N}$ application rate was higher in Jilin 
province than in Hebei (Table 2). Diesel fuel is also a large input of agricultural resources, in the range of $61.8 \sim 163.3 \mathrm{~kg} \mathrm{ha}^{-1}$ were used in over $80 \%$ of the total farms surveyed. Film was not used for crop production but in rice, where 5.5 8.5 $\mathrm{tha}^{-1}$ films were used in Jiangxi and Hunan.

\section{Carbon footprint}

The CF for rice, wheat and maize were $0.87,0.30$, and $0.24 \mathrm{kgCO}_{2}$-eq $\mathrm{kg}^{-1}$ at yield-scale, respectively. The CF of rice production was 2.9 and 3.6 times that of wheat and maize, respectively, largely attributable to higher $\mathrm{CH}_{4}$ emissions from paddy fields, which comprised $63 \%$ of the total value of $\mathrm{CF}$. The GHGs emissions associated with agricultural inputs were the second largest contributor to the CF of rice production, accounting for $27.4 \%$, while the $\mathrm{N}_{2} \mathrm{O}$ emissions from paddy fields had a small impact on the $\mathrm{CF}$ that it is negligible. Agricultural inputs were the secondary contributor to the CF of rice production, but was the largest secondary contributor to wheat and maize production, accounting for 65.4 and $74.5 \%$, respectively (Fig. 3). The GHGs emissions of synthetic fertilizers production and application (including $\mathrm{N}$ fertilizers, $\mathrm{P}_{2} \mathrm{O}_{5}$ fertilizers, and $\mathrm{K}_{2} \mathrm{O}$ fertilizers) were the most significant fractions of the total agricultural inputs, accounting for $40.2,47.3$ and $42.7 \%$ for rice, wheat and maize, respectively. The GHGs emissions from diverse forms of synthetic fertilizers followed the order: $\mathrm{N}$ fertilizers $>\mathrm{P}_{2} \mathrm{O}_{5}$ fertilizers $>\mathrm{K}_{2} \mathrm{O}$ fertilizers for all grain crops. In addition, GHGs emissions from $\mathrm{N}$ fertilizers of rice were higher than that of wheat and maize, but the opposite trend was found in $\mathrm{P}_{2} \mathrm{O}_{5}$ fertilizers. Following synthetic fertilizers, diesel oil consumption was the second largest contributor to GHGs emissions, accounting for $36.9,47.2$, and $40.9 \%$ for rice, wheat and maize, respectively. The GHGs emissions from seeds were significantly greater for the rice than that of wheat and maize. The GHGs emissions from pesticides, associated with herbicides, insecticides and fungicides were lowest, only accounting for $1.4,2.4$, and $3.1 \%$ for rice, wheat and maize, respectively. With regard to the different sources, field cultivation contributed the most to the $\mathrm{CF}$ of rice, while the production of agricultural inputs dominated the CF of wheat and maize. As seen in Table 4, the CF varied with farm size for among rice, wheat and maize, and rice and wheat were produced with a significantly lower CF (by $20 \sim 40 \%$ ) in large contractors than that in general household contractor, while no difference was observed for maize production in Hebei province.

\section{Nitrogen footprint}


The NF for the rice, wheat, and maize were 17.1, 14.3, and $6.8 \mathrm{~g} \mathrm{~N}$-eq kg-1 year $^{-1}$ at yield-scale,

333 respectively. The NF of maize was obviously less than that of wheat and rice, and similar between wheat and rice. Different to GHGs emissions, the Nr emissions of diesel oil consumption shared the largest percentage of agricultural inputs, being 471.4, 547.3, and $447.6 \mathrm{gN}-\mathrm{eq} \mathrm{ha}^{-1}$ year ${ }^{-1}$ for rice, wheat and maize, respectively. Next to diesel oil consumption, synthetic fertilizers emitted 278.7, 227.3,

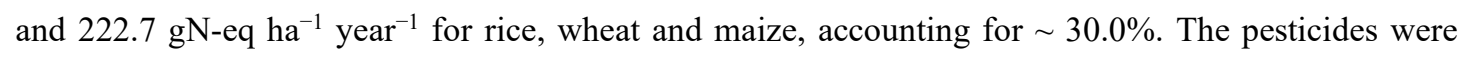
still the least contributor of $\mathrm{Nr}$ emissions in all grain crops, accounting for less than $2 \%$ of total $\mathrm{Nr}$ emissions from agricultural inputs. $\mathrm{NH}_{3}$ volatilization dominated $\mathrm{NF}$ from fields associated with $\mathrm{N}$ fertilizer applications for the all grain crop, accounting for $96.5,94.8$, and $96.0 \%$ for the rice, wheat, and maize, respectively. The $\mathrm{NH}_{4}{ }^{+}$leaching from maize fields had a small impact on the NF, was only

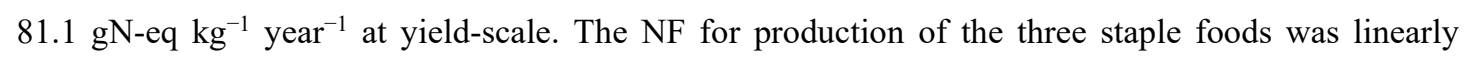
correlated with the CF (Fig. 4). In other words, the surveyed farms that produced higher GHG emissions also had higher Nr discharges. As such, the NF of rice production in Jiangxi province, wheat production in Jiangsu province, and maize production in Hebei province, were also higher than that in the other respective provinces (Table 3). The significant linear relationship between the CF and NF of food production from all the surveyed farms, attributed to the large contribution of $\mathrm{N}$ fertilizer to both $\mathrm{Nr}$ and GHG releases (Fig. 2). $\mathrm{N}$ fertilizer additions are known to promote the releases of various $\mathrm{Nr}$ species, linearly or exponentially, and it is widely accepted that $\mathrm{N}$ fertilizer use is a substantial source of GHG emissions during the life-cycle of cereal grain production. The synthetic $\mathrm{N}$ fertilizer inputs contributed more to the CF of the wheat and maize than to that of rice (Fig. 2); as a result, the linear relationship between the CF and NF was stronger for wheat $\left(R_{2}=0.69\right)$ and maize $\left(R_{2}=0.52\right)$, than for rice $\left(R_{2}=0.45\right)$ production (Fig. 4$)$.

\section{Eco-efficiency analysis}

As shown in Table 5, the eco-efficiency score of rice, wheat and corn production at a province level were $0.53,0.66$, and 0.89 based on a cumulative average, respectively. There was no significant difference in eco-efficiency scores between different provinces of the same crop. Corn in Jilin had the highest eco-efficiency score (0.91), which was significantly higher than that of wheat in Anhui (0.62) and corn in Hunan (0.51) by $45 \%$ and $76 \%$, respectively. When the eco-efficiency value is less than 1 , the numerical value of relaxation variable can reflect the cause of eco-efficiency loss. There was 
significant difference in operational targets of rice, wheat and corn production based on cumulative averages of SBM-DEA window analysis. The redundancy rates of yield, resources input and undesired output are all negative, which indicates that insufficient output is not the cause of eco-efficiency loss, but mainly lies in the excess of resources input and unexpected output. An increase in yields had only limited effects on improvement in eco-efficiency of rice, wheat and corn production because the yield increase potential rates were very small $(0.1 \sim 3.4 \%)$, and there were no significant differences in increase potentials of yields between provinces. Among the resources input factors, the main causes of crop eco-efficiency loss for rice are diesel consumption of harvest, electricity for irrigation and $\mathrm{N}$ fertilizer input. Inputs of diesel consumption of harvest, herbicides and $\mathrm{N}$ fertilizer are too much for the wheat production, and that of seed production, herbicides and $\mathrm{N}$ fertilizer for the corn production. From a perspective of environmental impact reduction potential rates, GWP $(22.7 \sim 25.1 \%)$ was more important for the environmental mitigation target than $\mathrm{Nr}(10.9 \sim 17.9 \%)$ in rice production, but the opposite scenario appears in wheat and corn production.

\section{Discussions}

\section{Carbon and nitrogen footprints from grain crop production}

The CF for the rice, wheat and maize in the study ranged from 0.84 to $0.90,0.27$ to 0.34 and 0.23 to $0.26 \mathrm{kgCO}_{2}$-eq $\mathrm{kg}^{-1}$ among provinces from all the surveyed farms, respectively. The corresponding $\mathrm{CF}$ for grain production in China were similar to wheat $\left(0.3 \mathrm{kgCO}_{2}\right.$-eq kg$\left.{ }^{-1}\right)$ and maize $\left(0.3 \mathrm{kgCO}_{2}\right.$-eq kg$\left.{ }^{-1}\right)$ production in Canada $[18,27]$, respectively. In our study, the estimated CF for rice is lower than in India, where rice yields are relatively low but energy costs for irrigation are high (Pathak et al., 2010). However, The CF for rice in the surveyed farms were little higher than the amounts of rice production in Japan $\left(0.8 \mathrm{kgCO}_{2}\right.$-eq $\left.\mathrm{kg}^{-1}\right)$ [25]. It may be due to the levels of agricultural inputs in China were generally larger than those in developed countries. Xu et al. [29] showed that the CF of rice production was $2.50,2.33,1.89,1.54$, and $1.34 \mathrm{~kg} \mathrm{CO}_{2}-\mathrm{eq} \mathrm{kg}^{-1}$ on yield-scale in Guangdong, Hunan, Heilongjiang, Sichuan and Jiangsu of China, respectively. Differences in crop carbon footprints are mainly attributed to differences in the sources of data collection and the emission factors of agricultural inputs at quality system boundaries as well as the calculation methods between studies. For example, different provinces have different requirements for irrigation. Compared with the agricultural areas in northern China where water resources are scarce, the Yangtze River basin has a smaller demand for irrigation due to its 
natural superior climate resources. In addition, due to the superior geographical features and climatic conditions, the yield of the Yangtze River basin is generally higher than that of other agricultural areas, resulting in a small CF per unit yield. The data presented herein indicate that average GHGs emissions from agricultural inputs were higher for the rice than those for wheat and maize, which may be due to greater applications of diesel oil, electricity, seeds, fertilizers and films for the rice, in spite of larger pesticide for the wheat and $\mathrm{P}_{2} \mathrm{O}_{5}$ fertilizers for the maize (Table 3). What is more, paddy rice cultivation is a primary contributor to global $\mathrm{CH}_{4}$ emissions, which was necessarily performed for rice cultivation in the farms surveyed. The $\mathrm{CH}_{4}$ emissions from paddy fields are the main component of $\mathrm{CF}$ in this study, similar to other studies [30]. Xue and Landis [31] estimated that the NF was $\sim 2.65 \mathrm{gN}^{-\mathrm{eq} \mathrm{kg}}{ }^{-1}$ of cereals production by using the LCA method in the Gulf of Mexico. Regarding the value of NF, our values are several orders of magnitude higher than the values obtained by Xue and Landis [31], which is similar to Pierer et al. [32], but this is due to the use of different sets of characterization factors for the calculation method. In addition, differences in nitrogen management during grain production are also possible reasons for differences in $\mathrm{Nr}$ loss. $\mathrm{NH}_{3}$ volatilization is the main $\mathrm{NF}$ source in food crop production, which is similar to the results reported by Leip et al [33]. The $\mathrm{NH}_{3}$ volatilization increased linearly with the $\mathrm{N}$ fertilizer application rates in among rice, wheat and maize seasons [24]. What is more, the NF of rice production were larger than that of wheat and maize production, primarily attributed to higher levels of $\mathrm{NH}_{3}$ volatilization during the rice growing seasons [15]. This trend may be due to the higher moisture and urea content in rice growing period, which is conducive to the improvement of soil urease activity, leading to the increase of $\mathrm{NH}_{4}{ }^{+}$concentration in paddy soil [24]. Moreover, compared to small sized household farms, the CF and NF in large sized farms were significantly lower (Table 4). The main reason is that farmers with large scale of land planting generally have a higher level of farmland management, which can more effectively control the production and application of agricultural materials, thus improving the utilization efficiency of water and fertilizer. Huang et al. [12] further proposed that planting scale has a negative impact on the fertilizer application of farmers, and land transfer should be increased to promote the concentration of land to some farmers so as to reduce the fertilizer application per unit area. This is consistent with the findings of Feng et al. [34], who reports that large farms ( $>0.7$ ha, $10 \mathrm{mu}$ ) may have 30 more topsoil organic carbon reserves than small farms (less than $0.7 \mathrm{ha}$ ) 


\section{Eco-efficiency of crop production}

423 Using DEA model and eco-efficiency assessment of LCA adopted by different research institute, as 424 Beltran-Esteve et al. [35], although only a few examples of eco-efficiency of economic angle of view 425 has always been the hot spot of the planting industry research, but it is not the focus of this study 426 pointed out in this study, we have some DEA model to consider the economic aspects of the production 427 process, such as Sahoo et al. [36] and Cherchye et al [37]; However, these models do not take into 428 account environmental impacts or the definition of ecological efficiency of the WBCSD. It should be 429 highlighted that we have focused the eco-efficiency assessment on producing more with fewer 430 resources and less environmental impacts as done initially by Lozano et al. [38]. Our results of 431 eco-efficiency assessment considering the whole agricultural input from major cereal crops of China 432 are reported in Fig.2. The eco-efficiency score of rice, wheat and corn production at a province level 433 were $0.53,0.66$, and 0.89 based on a cumulative average, respectively (Table 5). A direct comparison 434 among the results from different studies is not always straightforward, due to the different system 435 boundaries definition and assumptions. Zhu et al. [39] performed the eco-efficiency of rice cultivation 436 in China during 1995-2014 based a DEA index method. Due to different modeling assumption (e.g. 437 straw mulching and its economic impact on grain and straw distribution), their eco-efficiency score of 438 rice production are higher compared to our results by $33 \%$. With regard to Japan, our eco-efficiency 439 score of wheat is lower by $11.5 \%$, respectively. This is mainly due to the differences in wheat yield, i.e. $440 \quad 6.0 \mathrm{t} \mathrm{ha}^{-1}$ in our study and $9.7 \mathrm{~kg} \mathrm{ha}^{-1}$ in Japan, and differences in input, i.e. fertilizer, diesel oil and 441 pesticide. With regard to the contribution of unit processes, our findings are consistent with previous 442 studies that identified field emissions and fertilization as the main factors influencing the impact [40].

443 What is more, our study the impact on eco-efficiency was also dominated by diesel consumption of 444 harvest and electricity for irrigation, the deviation is probably due to the different contribution of these 445 input flows. With the rapid development of rural land transfer and agricultural mechanization in China 446 in recent years, problems such as excessive land management scale, mismatched management capacity 447 and scale, excessive investment in agricultural machinery, and low utilization efficiency have occurred 448 in some areas, leading to the loss of agricultural eco-efficiency. 
food production and reduced $\mathrm{CH}_{4}$ emissions (Table 2). Reduction of rice paddy field $\mathrm{CH}_{4}$ emissions would be an efficient solution toward lowering the $\mathrm{CF}$ of rice production. The use of appropriate farming practices could reduce $\mathrm{CH}_{4}$ emissions from paddy rice cultivation, in ways that tillage practice is optimized and water and fertilizer management is improved. Rational water resource management (such as intermittent irrigation, intermittent irrigation-drainage in mid-season-frequent waterlogging, non-waterlogging-drainage in mid-season-intermittent irrigation) was adopted to reduce $\mathrm{CH}_{4}$ emission compared with continuous flooding in rice growing season [41]. To both cut $\mathrm{N}$ inputs and enhance the grain yields, there is a need to greatly improve the $\mathrm{N}$ partial factor productivity (PFPN) on a national

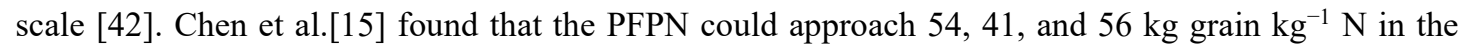
main agroecological areas, respectively, for rice, wheat and maize production in China; these levels are 3.6, 2.9 and 2.5 times than our values of 15.1, 13.9 and $22.8 \mathrm{~kg}_{\text {grain }} \mathrm{kg}^{-1} \mathrm{~N}$. In addition, for rice, the total nitrogen application should be divided into at least three stages: base fertilizer, early tillering and heading, which are effective in maintaining or even increasing rice yield, and can save $20 \sim 30 \%$ nitrogen fertilizer (Zhao et al., 2015). Concerning proper nitrogen management for wheat and maize, compared with the current one topdressing, two topdressing (one topdressing at the later stage of wheat and maize growth) was carried out, promoting the deep application of maize topdressing. Even in the case of reduced nitrogen application, it can also greatly increase the grain yield [15, 42]. Other measures, for example, soil tests such as a preplanting $\mathrm{NO}_{3}$ test is an effective method also can help avoid excessive use of $\mathrm{N}$ fertilizer [44]; the incorporation of $\mathrm{N}$ fertilizer into soil and banded $\mathrm{N}$ fertilizer placement minimize $\mathrm{N}$ losses such as $\mathrm{NH}_{3}$ volatilization and increase fertilizer efficiency; and the effect of the preceding stubble on nitrogen supply in grain pods reduced the amount of nitrogen applied to the next crop [46].

\section{Main uncertainties of the study}

In this study, $\mathrm{CF}$ and $\mathrm{NF}$ related environmental impacts and eco-efficiency of major cereal crops production is quantified with an integrated LCA and DEA approach. However, LCA results are strongly affected by the modeling assumptions and the inherent uncertainty connected with the definition of system boundary. Some of the limitations of our study are that, due to ignorance, certain aspects of planting have not been addressed, such as the impact of crop residues on crop rotation management, changes in the timing of current and new management practices, and the indirect effects of climate 
change on feed composition, fertilizer quality and irrigation. There was no information on the preceding crops in rotation, and thus the environmental benefits, such as $\mathrm{N}$ fertilizer reduction resulting from introducing grain legumes were unclear. In addition, $\mathrm{NH}_{3}$ volatilization loss rate under the same grain cropping system were used the same loss rate in the NF calculation of farmers' survey in each province, which may lead to some differences from the actual value due to the influence of soil properties, climatic conditions and farm management practices between regions [45]. Despite the above limitations, trends in $\mathrm{NH}_{3}$ contributions would likely not change for the NF of all grain crops. Further, toxicity to humans and various ecosystems and biodiversity, which were important environmental impact categories [46], were excluded because the sources of pesticide data are complex. However, despite these limitations, the fact remains that the environmental characteristics of rice, wheat and maize produced throughout China are best represented in this paper, using unified evaluation criteria

\section{Conclusion}

In this study, a combination of LCA and DEA was used to measure ecological efficiency, that is, crop yields under a single environmental impact index such as global warming and water eutrophication. The focus was on a comparison in rice, wheat and corn production at a province level in China by a farmer survey. The results showed that compared with those from the developed countries, the CFs for the three major grain crops in China were higher. Moreover, $\mathrm{N}$ fertilizer use was seen as the most important contributor (44 79\%) to the total CF of crop production, which was significantly correlated with $\mathrm{N}$ fertilizer application rate. Rice had a higher PCF $\left(0.87 \mathrm{kgCO}_{2}-\mathrm{eq} \mathrm{kg}^{-1}\right)$ than wheat $(0.30$ $\mathrm{kgCO}_{2}$-eq $\left.\mathrm{kg}^{-1}\right)$ and maize $\left(0.24 \mathrm{kgCO}_{2}\right.$-eq kg$\left.{ }^{-1}\right)$, mainly due to the high $\mathrm{CH}_{4}$ emission from rice fields. Meanwhile, the product NFs were 17.11, 14.26, and $6.83 \mathrm{~g} \mathrm{~N}-\mathrm{eq} \mathrm{kg}^{-1}$ for rice, wheat, and maize, respectively. In contrast to global production, the greater contributions of NF mean that cereal production depends more on $\mathrm{NH}_{3}$ volatilization in China. Furthermore, the significantly positive relationships between $\mathrm{CF}$ and NF indicate the potential for simultaneous mitigation in the regions with high agricultural inputs, e.g. fertilization amounts. On the basis of the above analysis, optimization of synthetic fertilizers application is necessary to reduce the NF of cereal production. The results of LCA-DEA indicated that the eco-efficiency of major cereal crops production was found to be inefficient. Additionally, based on DEA-based sustainability performance assessment results, major cereal crops production is found to be as the major driver of CF and NF with an approximate share of 
$51217 \sim 22 \%$ of the total impact. It also identified the target operational input for environmental measures

513 when practicing eco-efficient crop production. These findings should contribute to achieving 514 sustainable agriculture. Redundancy rate analysis is also provided, which indicated that diesel 515 consumption of harvest, electricity for irrigation, herbicides and $\mathrm{N}$ fertilizer input value dramatically 516 changes the overall eco-efficiency score. Based on previous studies, this study proves that the 517 combined application of LCA and DEA is a method suitable for the comprehensive ecological 518 efficiency evaluation of agricultural production

\section{Abbreviations}

C: carbon; CF: C footprints; N: nitrogen; NF: N footprints; LCA: LCA life cycle assessment; DEA: data envelopment analysis; GHGs: greenhouse gases; $\mathrm{CH}_{4}$ : methane; $\mathrm{N}_{2} \mathrm{O}$ : nitrous oxide; $\mathrm{Nr}$ : reactive $\mathrm{N}$; DMUs: decision-making units

\section{Funding}

This study was supported by the Project of National Key Research and Development Program of China (2016YFD0300210) and Project of National Natural Science Foundation of ZheJiang (LQ18G030013). for providing support in field survey in Jiangxi, Hunan, Jiangsu, Anhui, Jilin and Hebei Provinces of China. We also greatly thank Heshui Xu, Zhe Zhu and Changliang Shi for their suggestions in statistics analyses. Zhongdu Chen designed the study and writed the first draft; Chunchun Xu and Long Ji provided data and carried out formula analysis and performed the data analyses. Fuping Fang discussed the results and contributed to improving the manuscript. The dataset supporting the conclusions of this article is included within the article. Not applicable. 
crop distribution. Nat Geosci.

545 2. Van Grinsven H J, Holland M, Jacobsen B H, Klimont Z, Sutton M A, Jaap Willems W. Costs and benefits of nitrogen for Europe and implications for mitigation. Environ Sci Technol. 2013; 47: 3571-3579.

3. Angulo-Meza L, Marcela González-Araya Iriarte A, Rebolledo-Leiva R, João Carlos Soares de Mello. A multiobjective dea model to assess the eco-efficiency of agricultural practices within the CF + DEA method. Comput Electron Agr. 2018.

4. Notarnicola B, Sala S, Anton A, McLaren S J, Saouter E, Sonesson U. The role of life cycle assessment in supporting sustainable agri-food systems: A review ofthe challenges. J. Clean. Prod. 2017; 140: 399-409.

5. Yan M, Cheng K, Luo T, Yan Y, Pan G, Rees R M. Carbon footprint of grain crop production in China - based on farm survey data. J Clean Prod. 2015; 104, 130-138.

6. Leach A M, Galloway J N, Bleeker A, Erisman J W, Kohn R, Kitzes J. A nitrogen footprint model to help consumers understand their role in nitrogen losses to the environment. 2012. Environ Dev. 1, 40-66

7. Guinee J B. Handbook on Life Cycle Assessment: Operational Guide to the ISO Standards. Kluwer Academic Publishers, Dordrecht, The Netherlands. 2002.

8. Iribarren D, Vázquez-Rowe I, Moreira M T, Feijoo G. Further potentials in the joint implementation of life cycle assessment and data envelopment analysis. Sci. Total Environ. 2010; 408 (22): 5265-5272.

9. Vázquez-Rowe I, Iribarren Lorenzo D, Moreira M T, Feijoo Costa G. Combined application of life cycle assessment and data envelopment analysis as a methodological approach for the assessment of fisheries. Int. J. Life Cycle Assess. 2010; 15: $272-283$.

10. Rebolledo-Leiva R, Angulo-Meza L, Iriarte A, González-Araya M C. Joint carbon footprint assessment and data envelopment analysis for the reduction of greenhouse gas emissions in agriculture production. Sci. Total Environ. 2017; 593-594, 36-46

11. Otsuka A. Regional energy demand and energy efficiency in Japan: an application of economic analysis. 2016.

12. Huang J. Non-agricultural employment, planting scale and chemical fertilizer application-based on empirical test on rural fixed observation points. NanJin, MS Thesis, Nanjing Agriculture University (in Chinese). 2016.

13. Bai H, Tao F. Sustainable intensification options to improve yield potential and eco-efficiency for rice-wheat rotation system in China. Field Crops Res. 2017; 211: 89-105.

14. Liu S, Qin Y, Zou J, Liu Q. Effects of water regime during rice-growing season on annual direct $\mathrm{N}_{2} \mathrm{O}$ emission in a paddy rice-winter wheat rotation system in southeast China. Sci Total Environ. 2010; 408: 906-913.

15. Chen X, Cui Z, Fan M, Vitousek P, Zhao M, Ma W, Wang Z, Zhang W, Yan X, Yang J. Producing more grain with lower environmental costs. Nature. 2014; 514: 486-489.

16. Ray D K, Ramankutty N, Mueller N D, West P C, Foley J A. Recent patterns of crop yield growth and stagnation. Nat. Commun. 2012; 3: 1293.

576 17. Zhang F, Cui Z, Chen X, Ju X, Shen J, Chen Q, Liu X, Zhang W, Mi G, Fan M. Integrated nutrient management for food security and environmental quality in China. Adv Agron. 2012; 116: 1-40. 
19. IPCC (Intergovernmental Panel on Climate Change) (2006). IPCC Guidelines for National Greenhouse Gas Inventories. Institute for Global Environmental Strategies, Hayama, Kanagawa, Japan. 2006.

20. Liu X H, Gao W S, Zhu W S. Mechanism and Technical Pattern of Straw Returning. China Agriculture Press, Beijing. 2001 (in Chinese)

21. Lu F, Wang X K, Han B. Straw return to rice paddy: Soil carbon sequestration and increased methane emission. Chin J Appl Eco. 21(1), 99-108 (in Chinese). 2010.

22. Zou J W, Huang $\mathrm{Y}$, Zheng $\mathrm{X}$, Wang $\mathrm{Y}$. Quantifying direct $\mathrm{N}_{2} \mathrm{O}$ emissions in paddy fields during rice growing season in mainland China: dependence on water regime. Atmos. Environ. 2007; 41: 8030-8042.

23. ISO 14044., 2006. Environmental Management-Life Cycle Assessment-Requirements and Guidelines. International Organization for Standardization.

24. Wang C, Zhou W, Li Z Z, Liu X M, Sun G, Xia W J, Wang X B, Liu G R. 2012. Effects of different nitrogen application rates on ammonia volatilization from paddy fields under double-harvest rice system. Plant Nutr Fertil Sci. 18(2): 349-358 (in

25. Xia L, Ti C, Li B, Xia Y, Yan X. Greenhouse gas emissions and reactive nitrogen releases during the life-cycles of staple food

26. Tone K. A slacks-based measure of super-efficiency in data envelopment analysis. Eur J Oper Res. 2002; 143(1): $32-41$.

27. Jayasundara S, Wagner-Riddle C, Dias G, Kariyapperuma K A. Energy and greenhouse gas intensity of corn (Zea mays L.)

28. Pathak H, Jain N, Bhatia A, Patel J, Aggarwal P K. Carbon footprints of Indian food items. Agric Ecosyst Environ. 2010; 139: $66-73$.

29. Xu X, Zhang B, Liu Y, Xue Y, Di B. Carbon footprints of rice production in five typical rice districts in China. Acta Ecol Sin.

30. Cheng K, Yan M, Nayak D, Pan G X, Smith P, Zheng J F, Zheng J W. Carbon footprint of crop production in China: an analysis

31. Xue X B, Landis A E. Eutrophication potential of food consumption patterns. Environ Sci Technol. 2010; 44 (16): 6450-

34. Feng S, Tan S, Zhang A, Pan G, Qu F, Smith P. Effect of household land management on cropland topsoil organic carbon storage at plot scale in a red earth soil area of South China. J Agric Sci. 2011; 149: 557-566. function approach using life cycle analysis. Environ. Impact Assess. Rev. 2017; 63: 116-127. 
37. Cherchye L, De Rock B, Walheer B. Multi-output efficiency with good and bad outputs. Eur. J. Oper. Res. 2015; 240 (3): $872-881$.

618 38. Lozano S, Iribarren I, Moreira M, Feijoo G. The link between operational efficiency and environmental impacts. A joint application of life cycle assessment and data envelopment analysis. Sci. Total Environ. 2009; 407: 1744-1754. Xinjiang State Farms Economy, 2017; 7: 11-20 (in Chinese).

40. Korsaeth A, Henriksen T M, Roer A G, Strømman A H. Effects of regional variation in climate and SOC decay on global warming potential and eutrophication attributable to cereal production in Norway. Agric. Syst. 2014;127: 9-18.

624 41. Hou H J, Peng S Z, Xu J Z, Yang S H, Mao Z. Seasonal variations of CH4 and N2O emissions in response to water management of paddy fields located in Southeast China. Chemosphere 2012; 89 (7): 884-892.

42. Zhang F, Cui Z, Chen X, Ju X, Shen J, Chen Q, Liu X, ZhangW, Mi G, Fan M. Integrated nutrient management for food security and environmental quality in China. Adv Agron. 2012; 116: 1-40.

43. Zhao $M$, Tian $Y, M a ~ Y$, Zhang $M$, Yao $Y$, Xiong Z, Yin B, Zhu Z. Mitigating gaseous nitrogen emissions intensity from a Chinese rice cropping system through an improved management practice aimed to close the yield gap. Agric Ecosyst Environ. 2015; 203: 36-45.

44. Bundy L G, Andraski T W. Diagnostic tests for site-specific nitrogen recommendations for winter wheat. Agron J. 2004; 96, 608-614.

45. Sommer S G, Schjoerring J K, Denmead O T. Ammonia emission from mineral fertilizers and fertilized crops. Adv Agron. 2004; 82: 557-622. 


\section{$639 \quad$ Figures}

640 Fig.1 Geographical distribution of sites surveyed in China (The value in parenthesis is the number of 641 farms surveyed).

642 Fig.2 A simplified flow chart of rice, wheat and corn production. When measuring the DEA-based

643 eco-efficiency scores, GWP and $\mathrm{Nr}$ were selected as the DEA inputs by a grouping procedure based on 644 the correlation analysis.

645 Fig.3 The average carbon footprint (CF) and nitrogen footprint (NF) of rice, wheat, and maize 646 production base on a farms survey in China.

647 Fig.4 Correlations between the average carbon footprint (CF) and nitrogen footprint (NF) of staple food

648 (a, rice; b, wheat; c, maize) production in China $(P<0.01$ in all plots). Each data point represents a 649 farmer.

650

651 


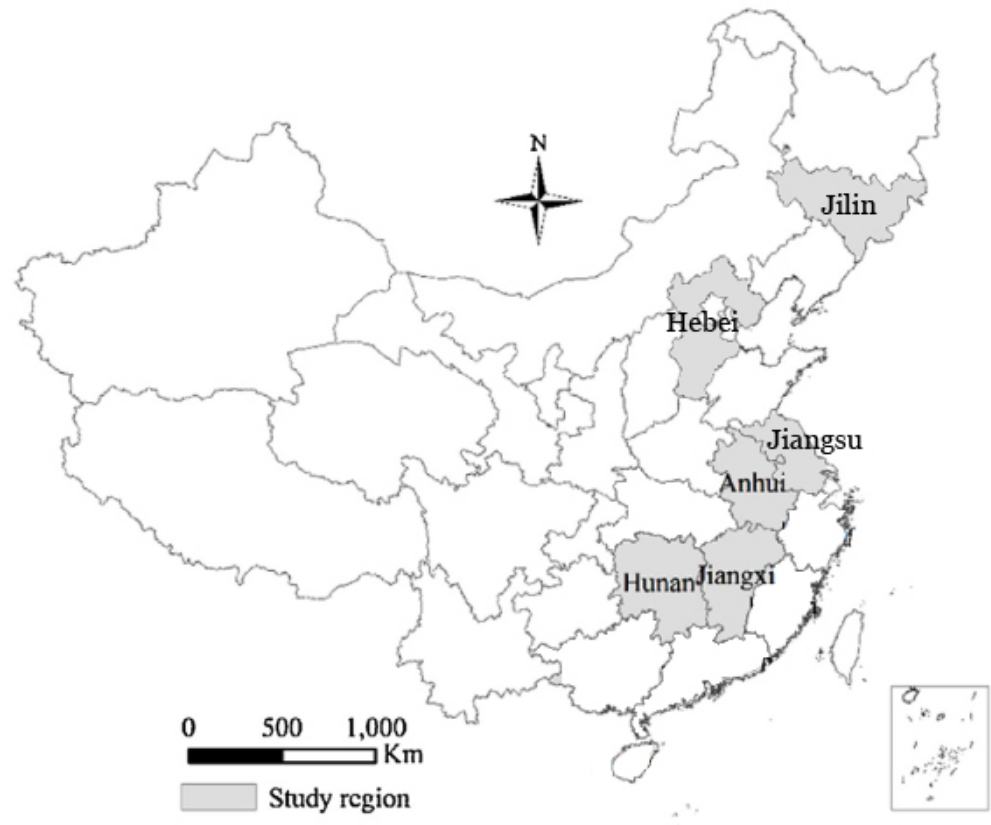

652

653 Fig. 1.

654 


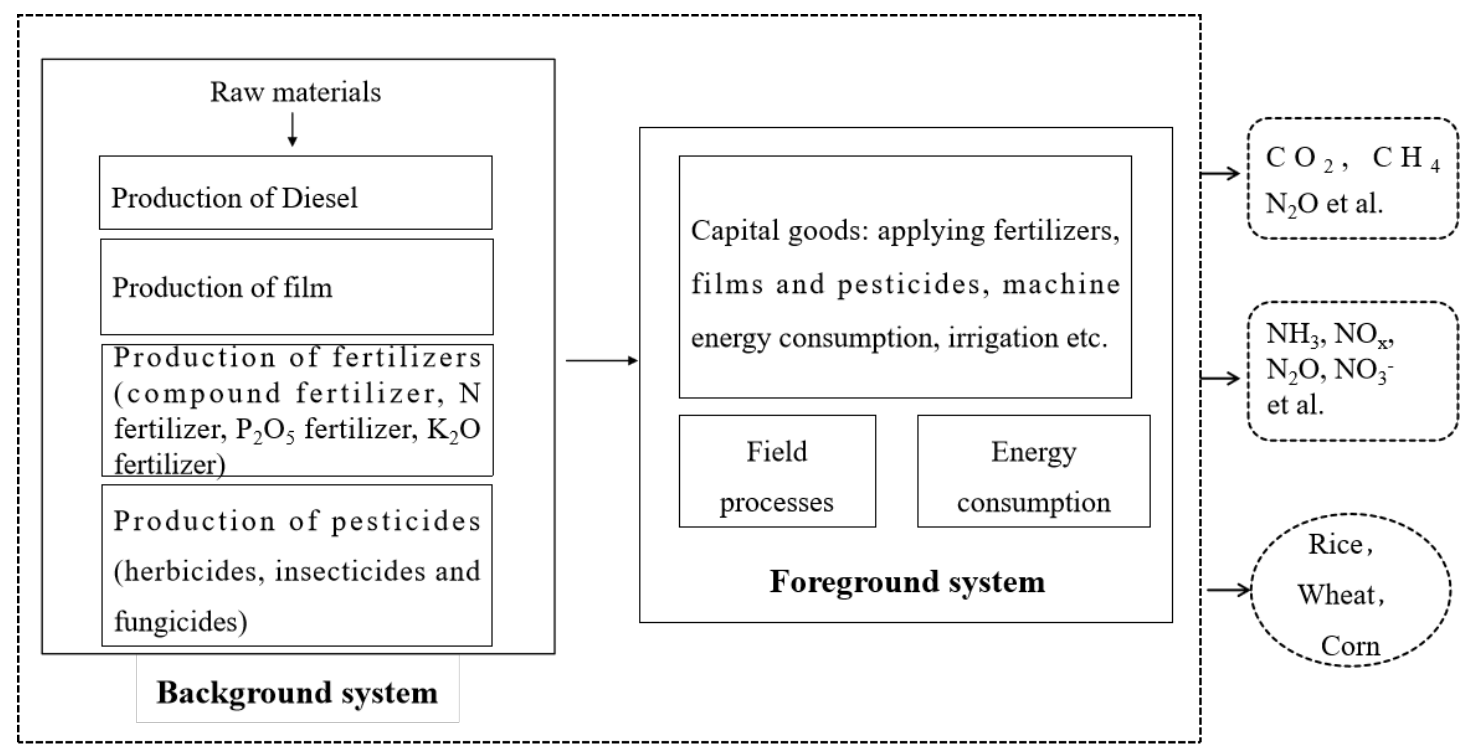

Fig.2 

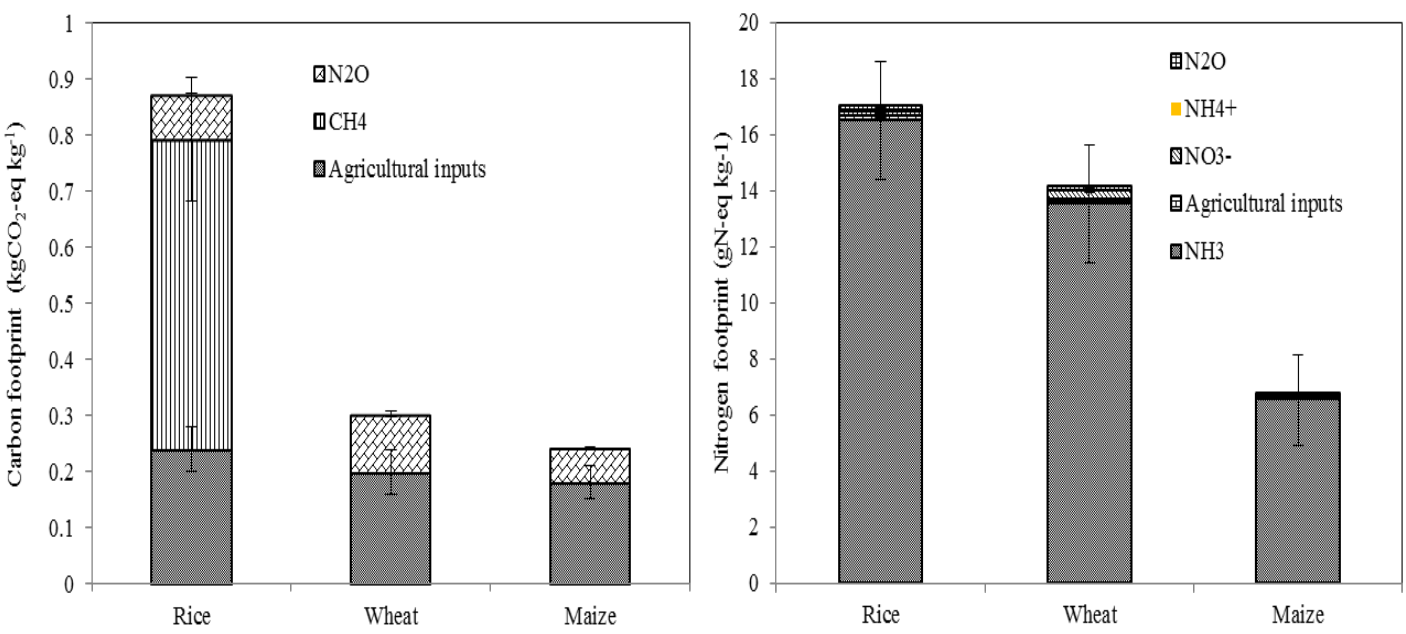

658

659

Fig. 3

660 

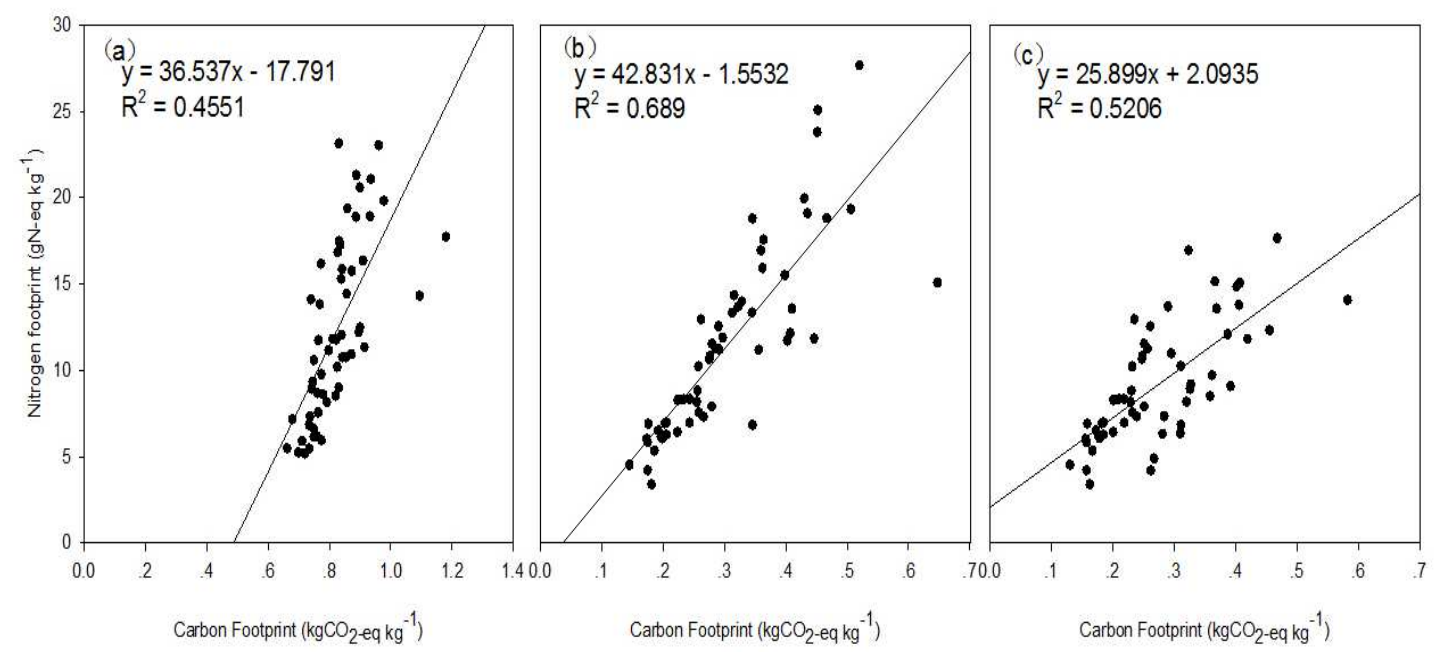

662

663

Fig.4

664

665 
Table 1 Independent variables and emissions factor of farm inputs for rice, wheat, and maize production in China.

\begin{tabular}{|c|c|c|c|c|}
\hline \multirow[b]{2}{*}{ Indicators } & \multirow{2}{*}{$\begin{array}{l}\text { Independent } \\
\text { variables }\end{array}$} & \multirow[b]{2}{*}{ Description of independent variables } & \multicolumn{2}{|c|}{ Coefficient } \\
\hline & & & $\begin{array}{l}\text { GHGs emission } \\
\left(\mathrm{kgCO}_{2} \text {-eq kg-1) }\right.\end{array}$ & 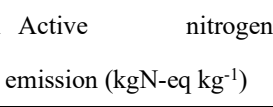 \\
\hline \multirow[t]{12}{*}{ Resources Input } & $\mathrm{N}$ & $\mathrm{N}$-fertilizer application rate per unit area $\left(\mathrm{kg} \mathrm{ha}^{-1}\right)$ & 1.53 & $0.89 \times 10^{-3}$ \\
\hline & $\mathrm{P}_{2} \mathrm{O}_{5}$ & $\mathrm{P}_{2} \mathrm{O}_{5}$-fertilizer application rate per unit area $\left(\mathrm{kg} \mathrm{ha}^{-1}\right)$ & 1.63 & $0.54 \times 10^{-3}$ \\
\hline & $\mathrm{K}_{2} \mathrm{O}$ & $\mathrm{K}_{2} \mathrm{O}$-fertilizer application rate per unit area $\left(\mathrm{kg} \mathrm{ha}^{-1}\right)$ & 0.65 & $0.03 \times 10^{-3}$ \\
\hline & Herbicides & Herbicides application rate per unit area $\left(\mathrm{kg} \mathrm{ha}^{-1}\right)$ & 16.61 & $3.53 \times 10^{-3}$ \\
\hline & Insecticides & Insecticides application rate per unit area $\left(\mathrm{kg} \mathrm{ha}^{-1}\right)$ & 10.15 & $4.49 \times 10^{-3}$ \\
\hline & Fungicides & Fungicides application rate per unit area $\left(\mathrm{kg} \mathrm{ha}^{-1}\right)$ & 10.5 & $7.05 \times 10^{-3}$ \\
\hline & Diesel & $\begin{array}{l}\text { Diesel consumption from machinery operation per unit } \\
\operatorname{area}\left(\mathrm{kg} \mathrm{ha}^{-1}\right)\end{array}$ & 4.99 & $4.66 \times 10^{-3}$ \\
\hline & Electricity & $\begin{array}{l}\text { Power consumption from irrigation per unit area }(\mathrm{kWh} \\
\left.\mathrm{ha}^{-1}\right)\end{array}$ & 0.82 & $0.12 \times 10^{-3}$ \\
\hline & Film & Film application rate per unit area $\left(\mathrm{kg} \mathrm{ha}^{-1}\right)$ & 22.72 & $12.03 \times 10^{-3}$ \\
\hline & Rice seed & Rice seed application rate per unit area $\left(\mathrm{kg} \mathrm{ha}^{-1}\right)$ & 1.84 & $0.76 \times 10^{-3}$ \\
\hline & Wheat seed & Wheat seed application rate per unit area $\left(\mathrm{kg} \mathrm{ha}^{-1}\right)$ & 0.58 & $0.24 \times 10^{-3}$ \\
\hline & Maize seed & Maize seed application rate per unit area $\left(\mathrm{kg} \mathrm{ha}^{-1}\right)$ & 1.93 & $0.88 \times 10^{-3}$ \\
\hline Expect output & Grain yield & Total crop yield per unit area $\left(\mathrm{kg} \mathrm{ha}^{-1}\right)$ & & \\
\hline \multirow[t]{2}{*}{ Undesired output } & Global warming & $\begin{array}{l}\text { Standardized global warming potential per unit area } \\
\left(\mathrm{kgCO}_{2} \text {-eq ha }{ }^{-1}\right)\end{array}$ & & \\
\hline & $\begin{array}{l}\text { Eutrophication } \\
\text { pollution }\end{array}$ & $\begin{array}{l}\text { Standardized eutrophication potentials per unit area } \\
\left(\mathrm{kgN}^{-\mathrm{eq} \mathrm{ha}} \mathrm{h}^{-1}\right)\end{array}$ & & \\
\hline
\end{tabular}


Table 2

673 The life cycle inventory dataset of farm size, grain yield, agricultural inputs and fields of rice, wheat and maize production in the surveyed regions (mean \pm S.E.)

\begin{tabular}{|c|c|c|c|c|c|c|}
\hline \multirow{2}{*}{ Item } & \multicolumn{2}{|c|}{ Rice } & \multicolumn{2}{|c|}{ Wheat } & \multicolumn{2}{|c|}{ Corn } \\
\hline & Jiangxi & Hunan & Jiangsu & Anhui & Hebei & Jilin \\
\hline Farm size (ha) & $2.1 \pm 0.5$ & $2.6 \pm 0.9$ & $2.4 \pm 1.1$ & $1.6 \pm 0.3$ & $0.6+0.2$ & $0.8+0.2$ \\
\hline Grain yield $\left(\mathrm{t} \mathrm{ha}^{-1}\right)$ & $6.0 \pm 0.4$ & $5.4 \pm 0.5$ & $5.7 \pm 0.8$ & $6.0 \pm 0.7$ & $6.7 \pm 0.6$ & $7.7 \pm 0.7$ \\
\hline Diesel oil $\left(\mathrm{L} \mathrm{ha}^{-1}\right)$ & $107.1 \pm 27.1$ & $95.2 \pm 33.4$ & $131.9 \pm 31.4$ & $103.0 \pm 29.0$ & $104.1 \pm 19.2$ & $88 \pm 10.3$ \\
\hline Electricity for irrigation $\left(\mathrm{kW} \mathrm{h} \mathrm{ha}^{-1}\right)$ & $27.3 \pm 8.5$ & $33.2 \pm 7.1$ & - & - & $91.8 \pm 14.4$ & $80.1 \pm 10.9$ \\
\hline Seeds $\left(\mathrm{kg} \mathrm{ha}^{-1}\right)$ & $78.6 \pm 14.0$ & $36.0 \pm 17.8$ & $44.2 \pm 9.7$ & $55.5 \pm 6.6$ & $44.6 \pm 7.6$ & $35.5 \pm 5.1$ \\
\hline Films $\left(\mathrm{kg} \mathrm{ha}^{-1}\right)$ & $7.4 \pm 1.1$ & $7.0 \pm 1.5$ & - & - & - & - \\
\hline Herbicides $\left(\mathrm{kg} \mathrm{ha}^{-1}\right)$ & $0.3 \pm 0.1$ & $0.3 \pm 0.2$ & $0.5 \pm 0.2$ & $0.3 \pm 0.1$ & $1.9 \pm 0.4$ & $1.4 \pm 0.7$ \\
\hline Insecticides $\left(\mathrm{kg} \mathrm{ha}^{-1}\right)$ & $0.4 \pm 0.2$ & $0.3 \pm 0.2$ & $0.6 \pm 0.2$ & $0.5 \pm 0.1$ & $0.7 \pm 0.2$ & $0.6 \pm 0.3$ \\
\hline Fungicides $\left(\mathrm{kg} \mathrm{ha}^{-1}\right)$ & $1.1 \pm 0.4$ & $0.8 \pm 0.5$ & $1.1 \pm 0.5$ & $1.0 \pm 0.4$ & $0.3 \pm 0.1$ & $0.2 \pm 0.1$ \\
\hline $\mathrm{N}$ fertilizers $\left(\mathrm{kg} \mathrm{ha}^{-1}\right)$ & $363.2 \pm 97.4$ & $217.0 \pm 96.3$ & $272.4 \pm 83.1$ & $197.3 \pm 57.1$ & $172.8 \pm 31.1$ & $200.3 \pm 37.0$ \\
\hline $\mathrm{P}_{2} \mathrm{O}_{5}$ fertilizers $\left(\mathrm{kg} \mathrm{ha}^{-1}\right)$ & $31.5 \pm 14.1$ & $36.1 \pm 7.8$ & $25.1 \pm 9.7$ & $35.2 \pm 9.7$ & $93.7 \pm 30.1$ & $107.6 \pm 39.7$ \\
\hline $\mathrm{K}_{2} \mathrm{O}$ fertilizers $\left(\mathrm{kg} \mathrm{ha}^{-1}\right)$ & $67.0 \pm 23.0$ & $86.9 \pm 30.0$ & $56.2 \pm 18.6$ & $78.1 \pm 25.7$ & $63.86 \pm 16.7$ & $91.1 \pm 26.7$ \\
\hline $\mathrm{CH}_{4}\left(\mathrm{~kg} \mathrm{ha}^{-1}\right)$ & $131.3 \pm 19.5$ & $121.1 \pm 29.5$ & - & - & - & - \\
\hline $\mathrm{N}_{2} \mathrm{O}\left(\mathrm{kg} \mathrm{ha}^{-1}\right)$ & $1.9 \pm 0.5$ & $1.2 \pm 0.5$ & $2.0 \pm 0.4$ & $1.4 \pm 0.3$ & $1.3 \pm 0.2$ & $1.5+0.3$ \\
\hline $\mathrm{NH}_{3}\left(\mathrm{~kg} \mathrm{ha}^{-1}\right)$ & $149.04 \pm 39.5$ & $89.07 \pm 40.0$ & $90.9 \pm 34.1$ & $65.9 \pm 23.1$ & $47.2 \pm 13.2$ & $55 \pm 21.2$ \\
\hline $\mathrm{NO}_{3}^{-}\left(\mathrm{kg} \mathrm{ha}^{-1}\right)$ & $4.9 \pm 0.5$ & $2.9 \pm 0.9$ & $7.3 \pm 1.0$ & $5.3 \pm 0.7$ & $1.4 \pm 0.1$ & $1.6 \pm 0.2$ \\
\hline $\mathrm{NH}_{4}^{+}\left(\mathrm{kg} \mathrm{ha}^{-1}\right)$ & $1.6 \pm 0.4$ & $1.0 \pm 0.5$ & $0.7 \pm 0.01$ & $0.5 \pm 0.01$ & $0.1 \pm 0.02$ & $0.1 \pm 0.03$ \\
\hline
\end{tabular}


Table 3

678 The average hidden greenhouse gases (GHGs) and reactive nitrogen ( $\mathrm{Nr}$ ) emissions from agricultural inputs of grain crop production in China $($ mean \pm S.E. $)$

\begin{tabular}{|c|c|c|c|c|c|c|}
\hline \multirow{2}{*}{ Input } & \multicolumn{3}{|c|}{ GHGs emission $\left(\mathrm{kg} \mathrm{CO}_{2}\right.$-eq ha-1) } & \multicolumn{3}{|c|}{$\mathrm{Nr}$ emission $\left(\mathrm{g} \mathrm{N}\right.$-eq ha $\left.^{-1}\right)$} \\
\hline & Rice & Wheat & Corn & Rice & Wheat & Corn \\
\hline Diesel oil & $504.7 \pm 134.1$ & $451.3 \pm 149.7$ & $479.3 \pm 134.1$ & $471.4 \pm 139.8$ & $547.3 \pm 140.1$ & $447.6 \pm 77.1$ \\
\hline Electricity for irrigation & $24.8 \pm 6.6$ & - & $70.7 \pm 13.1$ & $3.6 \pm 0.9$ & - & $10.3 \pm 1.8$ \\
\hline Seeds & $105.4 \pm 25.8$ & $28.9 \pm 4.6$ & $77.3 \pm 11.6$ & $43.5 \pm 10.6$ & $12.0 \pm 1.9$ & $35.2 \pm 5.8$ \\
\hline Films & $163.6 \pm 23.8$ & - & - & $86.6 \pm 11.8$ & - & - \\
\hline Herbicides & $5.0 \pm 1.7$ & $6.6 \pm 3.1$ & $27.4 \pm 8.3$ & $1.1 \pm 0.4$ & $1.4 \pm 0.7$ & $5.8 \pm 1.8$ \\
\hline Insecticides & $3.6 \pm 1.6$ & $5.6 \pm 1.1$ & $6.6 \pm 2.1$ & $1.6 \pm 0.8$ & $2.5 \pm 0.6$ & $2.9 \pm 1.2$ \\
\hline Fungicides & $10.0 \pm 5.0$ & $11.0 \pm 4.8$ & $2.6 \pm 1.2$ & $6.7 \pm 2.1$ & $7.4 \pm 2.8$ & $1.8 \pm 0.8$ \\
\hline $\mathrm{N}$ fertilizers & $443.9 \pm 144.4$ & $359.3 \pm 107.1$ & $285.4 \pm 52.2$ & $258.2 \pm 86.3$ & $209.0 \pm 62.3$ & $166.0 \pm 30.6$ \\
\hline $\mathrm{P}_{2} \mathrm{O}_{5}$ fertilizers & $55.1 \pm 17.1$ & $49.1 \pm 5.2$ & $164.1 \pm 18.9$ & $18.3 \pm 6.1$ & $16.3 \pm 1.6$ & $54.4 \pm 6.6$ \\
\hline $\mathrm{K}_{2} \mathrm{O}$ fertilizers & $50.0 \pm 17.1$ & $43.6 \pm 14.3$ & $50.4 \pm 14.1$ & $2.3 \pm 0.8$ & $2.0 \pm 0.7$ & $2.3 \pm 0.7$ \\
\hline Totals & $1366.0 \pm 234.1$ & $955.6 \pm 194.4$ & $1163.8 \pm 224.1$ & $893.2 \pm 187.2$ & $797.9 \pm 104.7$ & $726.4 \pm 100.7$ \\
\hline
\end{tabular}


683 Variation of product carbon footprint and nitrogen footprint with farm size classes (Mean \pm S.E.).

\begin{tabular}{|c|c|c|c|c|c|c|c|}
\hline \multirow{2}{*}{ Crop } & \multirow{2}{*}{ Region } & \multicolumn{3}{|c|}{ Carbon Footprint $\left(\mathrm{kgCO}_{2}\right.$-eq kg $\left.{ }^{-1}\right)$} & \multicolumn{3}{|c|}{ Nitrogen footprint ( $\mathrm{gN}^{\left.-\mathrm{eq} \mathrm{kg}^{-1}\right)}$} \\
\hline & & $\mathrm{LZF}$ & MZF & SZF & LZF & MZF & SZF \\
\hline \multirow[t]{2}{*}{ Rice } & Jiangxi & $0.80 \pm 0.12 \mathrm{~b}$ & $0.89 \pm 0.15 b$ & $1.12 \pm 0.07 \mathrm{a}$ & $17.47 \pm 3.11 \mathrm{~b}$ & $20.44 \pm 1.31 \mathrm{~b}$ & $24.07 \pm 2.01 \mathrm{a}$ \\
\hline & Hunan & $0.78 \pm 0.11 \mathrm{a}$ & $0.82 \pm 0.13 \mathrm{a}$ & $0.98 \pm 0.14 \mathrm{a}$ & $12.05 \pm 2.11 \mathrm{a}$ & $13.85 \pm 3.08 \mathrm{a}$ & $16.03 \pm 3.21 \mathrm{a}$ \\
\hline \multirow[t]{2}{*}{ Wheat } & Jiangsu & $0.26 \pm 0.04 \mathrm{c}$ & $0.35 \pm 0.01 b$ & $0.40 \pm 0.02 \mathrm{a}$ & $14.17 \pm 2.01 \mathrm{c}$ & $17.01 \pm 1.41 \mathrm{~b}$ & $19.12 \pm 1.11 \mathrm{a}$ \\
\hline & Anhui & $0.22 \pm 0.04 \mathrm{c}$ & $0.28 \pm 0.01 \mathrm{~b}$ & $0.31 \pm 0.01 \mathrm{a}$ & $9.88 \pm 3.22 \mathrm{c}$ & $11.64 \pm 1.42 \mathrm{~b}$ & $15.87 \pm 1.33 \mathrm{a}$ \\
\hline \multirow[t]{2}{*}{ Corn } & Hebei & $0.25 \pm 0.02 \mathrm{a}$ & $0.27 \pm 0.02 \mathrm{a}$ & $0.30 \pm 0.02 \mathrm{a}$ & $5.96 \pm 2.37 \mathrm{a}$ & $6.86 \pm 1.41 \mathrm{a}$ & $8.61 \pm 2.13 \mathrm{a}$ \\
\hline & Jilin & $0.20 \pm 0.03 \mathrm{~b}$ & $0.24 \pm 0.02 b$ & $0.29 \pm 0.01 \mathrm{a}$ & $5.46 \pm 0.67 \mathrm{~b}$ & $6.84 \pm 0.44 \mathrm{~b}$ & $7.94 \pm 0.53 \mathrm{a}$ \\
\hline
\end{tabular}

Household farms were divided into two categories of small sized (SZF, $<0.7$ ha), middle sized (MZF, 2-7 ha) and large sized household 
The eco-efficiency and redundancy rate of grain crop production on province levels in China (mean \pm S.E.)

\begin{tabular}{|c|c|c|c|c|c|c|}
\hline \multirow{2}{*}{ Item } & \multicolumn{2}{|c|}{ Rice } & \multicolumn{2}{|c|}{ Wheat } & \multicolumn{2}{|c|}{ Corn } \\
\hline & Jiangxi & Hunan & Jiangsu & Anhui & Hebei & Jilin \\
\hline \multicolumn{7}{|l|}{ Eco-efficiency } \\
\hline & $0.55 \pm 0.15$ & $0.51 \pm 0.13$ & $0.69 \pm 0.24$ & $0.62 \pm 0.21$ & $0.87 \pm 0.15$ & $0.91 \pm 0.13$ \\
\hline \multicolumn{7}{|c|}{ Undesired yield redundancy rate } \\
\hline Labor & $0.4 \%$ & $0.3 \%$ & $-0.2 \%$ & $-2.6 \%$ & $-1.1 \%$ & $2.0 \%$ \\
\hline Seeds & $-7.3 \%$ & $-5.7 \%$ & $-8.8 \%$ & $-9.3 \%$ & $-10.4 \%$ & $-10.9 \%$ \\
\hline Tillage & $-10.6 \%$ & $-12.0 \%$ & $-10.0 \%$ & $-15.4 \%$ & $-9.9 \%$ & $-14.5 \%$ \\
\hline Sowing & $-2.8 \%$ & $-5.4 \%$ & $-1.9 \%$ & $-6.1 \%$ & $-7.9 \%$ & $-4.5 \%$ \\
\hline Harvest & $-17.7 \%$ & $-19.9 \%$ & $-17.4 \%$ & $-16.8 \%$ & $-7.9 \%$ & $-4.5 \%$ \\
\hline Electricity for irrigation & $-17.9 \%$ & $-15.0 \%$ & & & $-7.7 \%$ & $-4.6 \%$ \\
\hline Herbicides & $-8.7 \%$ & $-4.3 \%$ & $-12.5 \%$ & $-14.1 \%$ & $-16.8 \%$ & $-23.3 \%$ \\
\hline Insecticides & $-8.1 \%$ & $-4.2 \%$ & $-1.3 \%$ & $-1.7 \%$ & $-19.1 \%$ & $-15.3 \%$ \\
\hline Fungicides & $-0.2 \%$ & $-0.6 \%$ & $-2.9 \%$ & $-9.9 \%$ & $-2.7 \%$ & $-9.2 \%$ \\
\hline $\mathrm{N}$ fertilizers & $-17.9 \%$ & $-20.9 \%$ & $-24.6 \%$ & $-32.9 \%$ & $-31.7 \%$ & $-31.3 \%$ \\
\hline $\mathrm{P}_{2} \mathrm{O}_{5}$ fertilizers & $-3.9 \%$ & $-2.0 \%$ & $6.8 \%$ & $-0.5 \%$ & $-7.9 \%$ & $-3.4 \%$ \\
\hline $\mathrm{K}_{2} \mathrm{O}$ fertilizers & $-2.6 \%$ & $-4.9 \%$ & $4.0 \%$ & $-0.7 \%$ & $-11.0 \%$ & $-5.5 \%$ \\
\hline Grain yield & $-0.4 \%$ & $-0.1 \%$ & $-1.3 \%$ & $-2.7 \%$ & $-3.4 \%$ & $-1.1 \%$ \\
\hline GWP & $-25.1 \%$ & $-22.7 \%$ & $-12.5 \%$ & $-13.1 \%$ & $-14.0 \%$ & $-13.5 \%$ \\
\hline $\mathrm{N}_{\mathrm{r}}$ & $-17.9 \%$ & $-10.9 \%$ & $-24.5 \%$ & $-23.0 \%$ & $-20.2 \%$ & $-20.6 \%$ \\
\hline
\end{tabular}




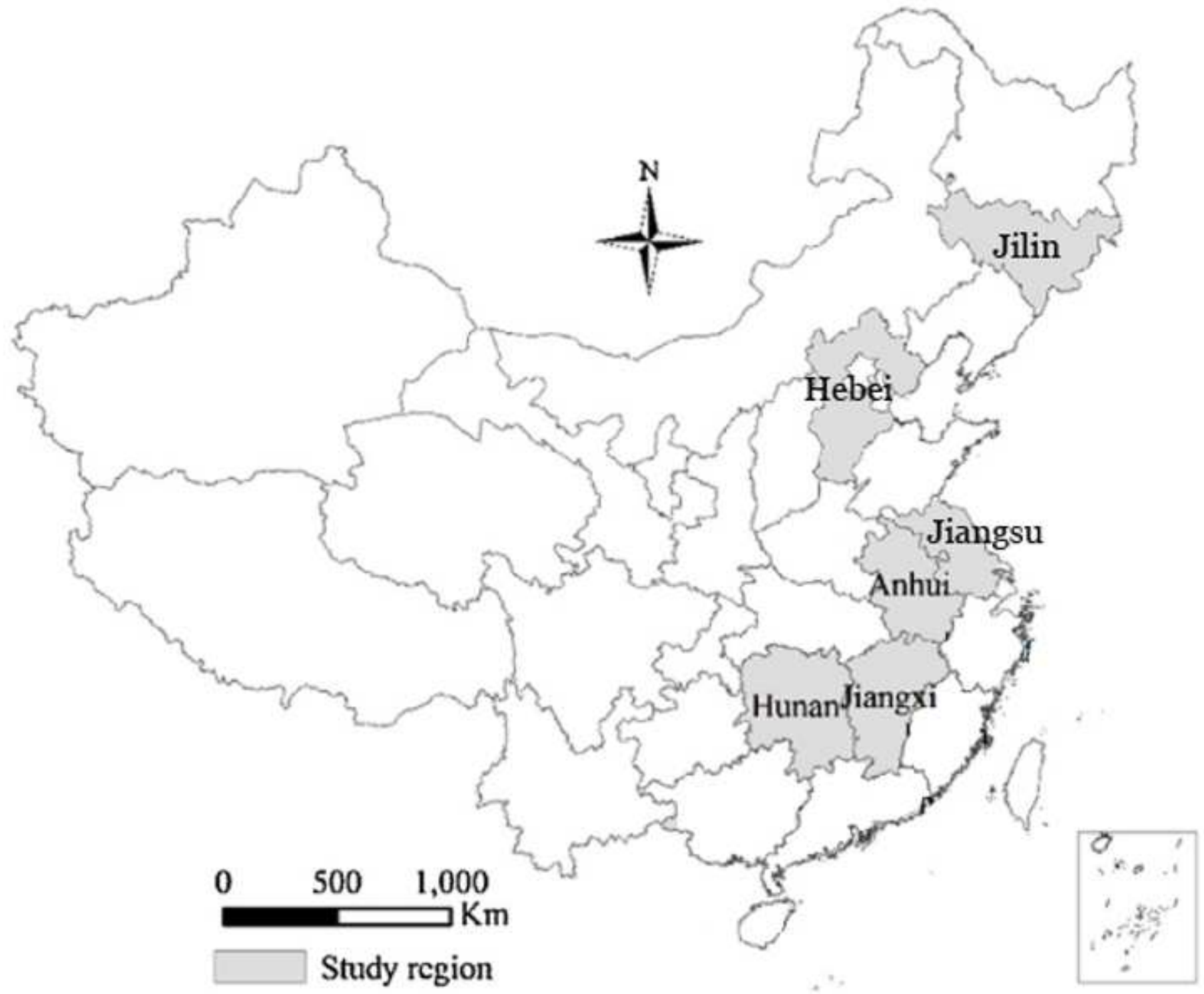

\section{Figure 1}

Geographical distribution of sites surveyed in China (The value in parenthesis is the number of farms surveyed). Note: The designations employed and the presentation of the material on this map do not imply the expression of any opinion whatsoever on the part of Research Square concerning the legal status of any country, territory, city or area or of its authorities, or concerning the delimitation of its frontiers or boundaries. This map has been provided by the authors. 


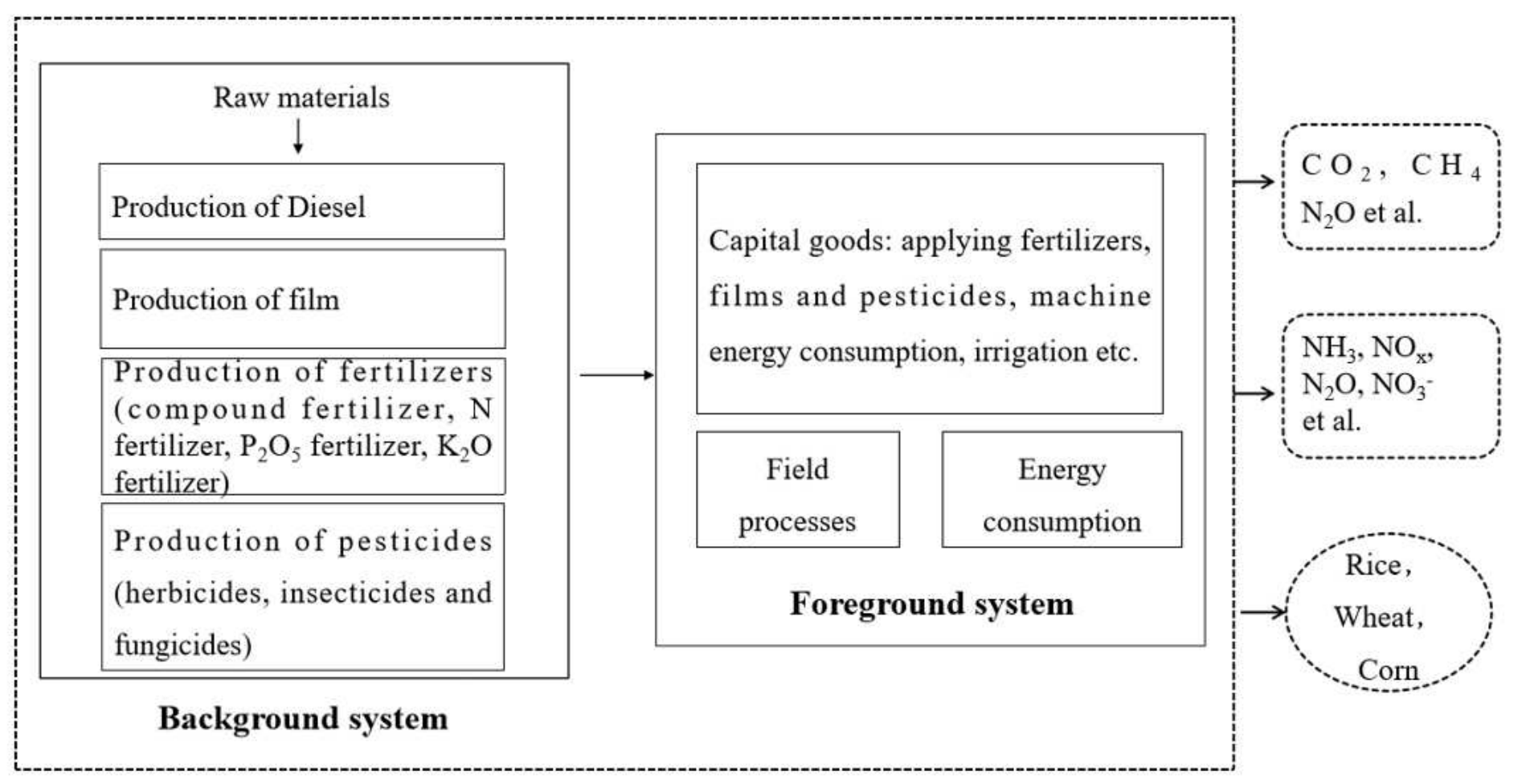

System boundary

Figure 2

A simplified flow chart of rice, wheat and corn production. When measuring the DEA-based eco-efficiency scores, GWP and Nr were selected as the DEA inputs by a grouping procedure based on the correlation analysis.
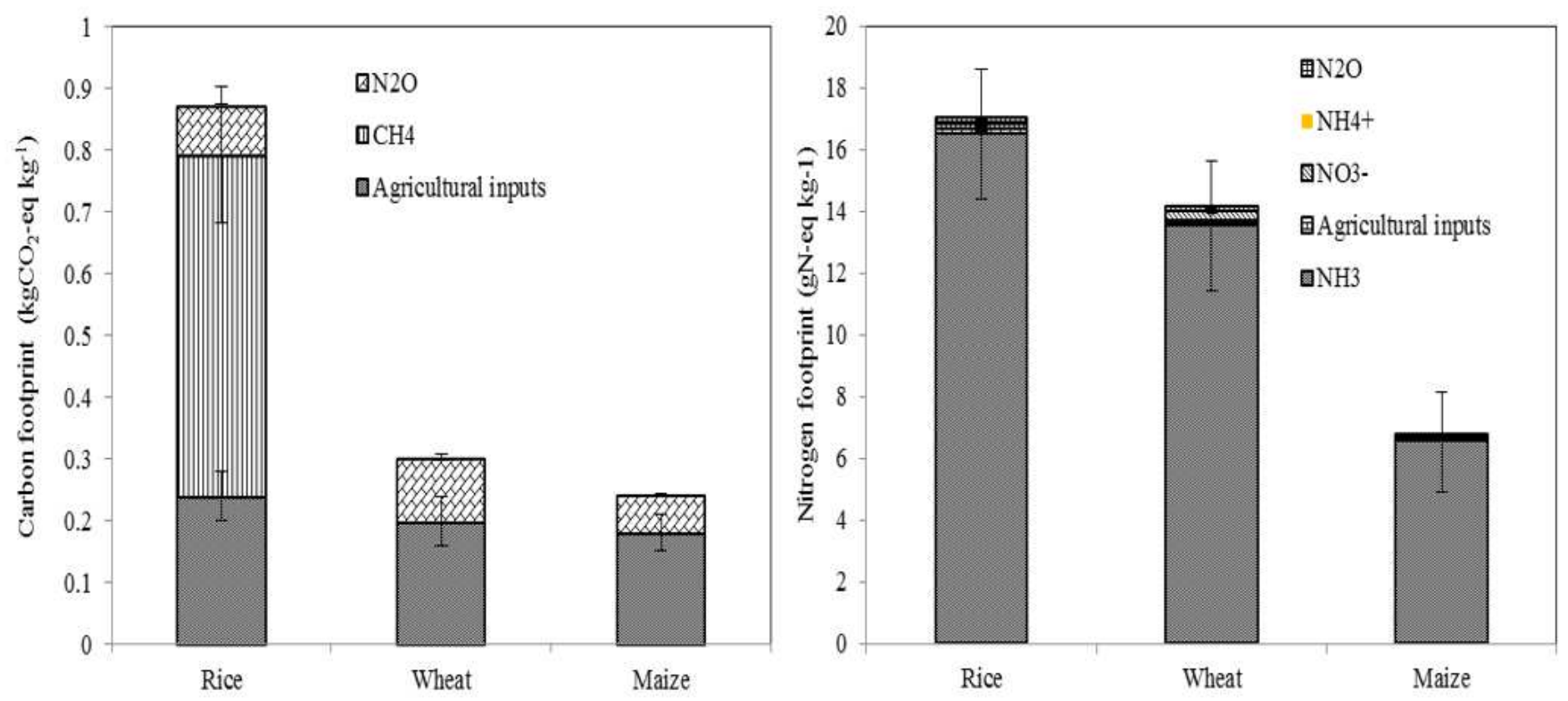

Figure 3 
The average carbon footprint (CF) and nitrogen footprint (NF) of rice, wheat, and maize production base on a farms survey in China.
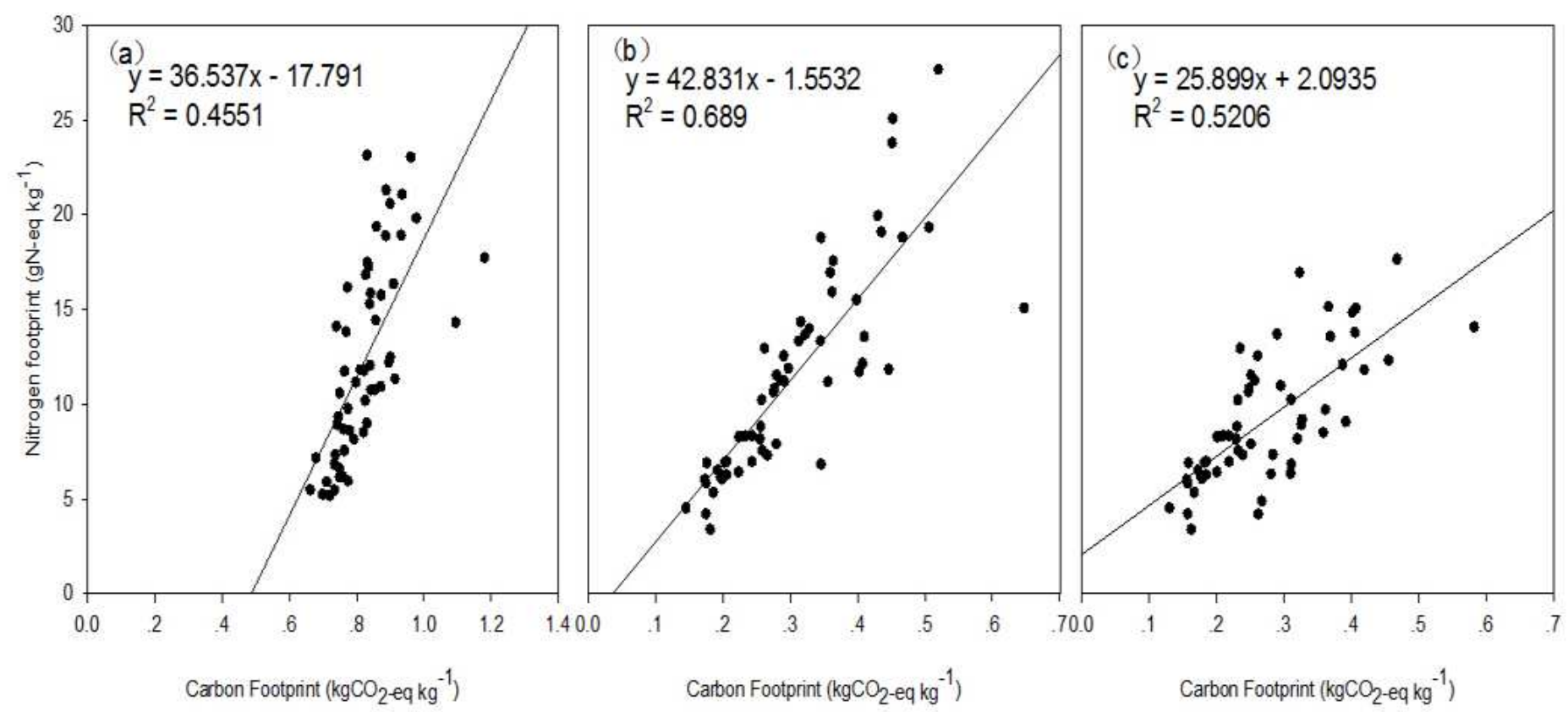

Figure 4

Correlations between the average carbon footprint (CF) and nitrogen footprint (NF) of staple food (a, rice; $\mathrm{b}$, wheat; $\mathrm{c}$, maize) production in China $(\mathrm{P}<0.01$ in all plots). Each data point represents a farmer. 